\title{
SREBRNE WYPOSAŻENIE ŚREDNIOWIECZNEGO OLTARZA ŚW. STANISŁAWA W KATEDRZE KRAKOWSKIEJ
}

Badania nad ołtarzem św. Stanisława w katedrze krakowskiej zainaugurowane już w 2. połowie XIX w. przez księży Ludwika Łętowskiego i Ignacego Polkowskiego, kontynuowane były w kolejnym stuleciu, a ich uwieńczeniem stało się monograficzne opracowanie autorstwa Michała Rożka, opublikowane w 1979 r. przy okazji obchodów 900. rocznicy męczeńskiej śmierci Patrona Polski ${ }^{1}$. Mimo licznych opracowań dotyczących architektury barokowej konfe$\mathrm{sji}^{2}$ oraz kolejnych trumien-relikwiarzy ${ }^{3}$ wiele kwestii historycznych oraz historyczno-artystycznych nie zostało dotąd rozwiązanych. Na nowe ujęcie zasługuje

\footnotetext{
${ }^{1}$ Ważniejsze opracowania ogólne: L. Ł e t o w s k i, Katedra krakowska na Wawelu, Kraków 1859, s. 19-20; I. P o l k o w s k i, Grób i trumna św. Stanistawa biskupa i męczennika na Wawelu. Studyum archeologiczno-historyczne, Sprawozdania Komisyi do Badania Historyi Sztuki w Polsce, III, 1888, s. 25-37; T. W o j c i e c h o w s k i, Kościót katedralny na Wawelu, Kraków 1900, s. 86-96; M. R o ż e k, Ara Patriae. Dzieje grobu św. Stanistawa w katedrze na Wawelu, s. 435-440, ACr XI (1979); M. R o ż e k, Katedra wawelska w XVII wieku, Kraków 1980, BK 121 , s. $68-110$.

${ }^{2} \mathrm{~K} . \mathrm{K}$ u trze bi a n k a, Mauzoleum świętego Stanistawa w katedrze na Wawelu, Kraków 1925; A. B o chnak, Kościół śs. Piotra i Pawła w Krakowie, PKHS IX (1948), s. 119; M. K a r po w i c z, Matteo Castello architekt wczesnego baroku, Warszawa 1994, s. 63-66.

${ }^{3} \mathrm{~A}$. B o c h n a k, Eksport z miast pruskich $w$ gtab Polski $w$ zakresie rzemiosta artystycznego, „Studia Pomorskie" II (1957), s. 84-90; E. Ś n i e ż y ń s k a - S t o l o t, Ze studiów nad ikonografia legendy św. Stanistawa biskupa, FHA VIII (1972), s. 174-179; W. W o j ty ń s k a, W sprawie autorstwa relikwiarza sarkofagowego siw. Stanisława $w$ katedrze na Wawelu, BHS XXXVI (1974), s. 233-236; M. W o źn i a k, Wpływy augsburskie w ztotnictwie gdańskim XVII $i$ XVIII stulecia, BHS XLVII (1985), s. 105-106; M. K o ch a now s k a-R e i ch e, Najstarsze cykle narracyjne z legenda św. Stanistawa biskupa, „Ikonotheka. Prace Instytutu Historii Sztuki Uniwersytetu Warszawskiego" 3 (1991), s. 27-48; D. N o w a c k i, Warsztat ztotnika gdańskiego Petera II Rodego, RHS XXVII (2002), s. 114-116, 125, poz. 56.
} 
przede wszystkim zagadnienie najstarszego grobu i ołtarza Męczennika w katedrze romańskiej. Na poważne potraktowanie zasługują też niedawno wysunięte przez Mariusza Karpowicza propozycje atrybucyjne względem kaplicy wzniesionej przez bp. Marcina Szyszkowskiego w drugim dziesięcioleciu w. XVII. $\mathrm{Na}$ uboczu badań pozostały dekorujące ją rzeźby i malowidła. Brakuje systematycznego zestawienia ruchomego wyposażenia ołtarza (naczynia, tkaniny liturgiczne itp.) oraz składanych przy nim wotów. Poważnym zadaniem stojącym przed historykami jest pełne opracowanie kultu św. Stanisława, oczywiście z uwzględnieniem liturgii sprawowanej przy jego relikwiach w katedrze.

Niniejszy tekst ma zapełnić jedynie kilka luk w wiedzy na temat Stanisławowego grobu. Poświęcony został tylko tym elementom jego wyposażenia powstałym w okresie średniowiecza, które wykonano ze srebra. Znamy je tylko z przekazów archiwalnych - ich ranga artystyczna i historyczna skłania jednak do ich przypomnienia oraz, o ile na to pozwalają źródła, szerszego omówienia.

O srebrnej trumnie, w której spoczywały relikwie św. Stanisława do momentu nowej fundacji dokonanej przez króla Zygmunta III Wazę w r. 1633, pisano wielokrotnie. Idąc za różnymi, nieprecyzyjnymi, a nawet sprzecznymi przekazami źródłowymi, badacze przyjmowali różne datowanie i łączyli ją $\mathrm{z}$ różnymi fundatorami.

W literaturze ostatnich kilku dziesięcioleci najczęściej przypisywano fundację relikwiarza księżnej Kindze, żonie Bolesława Wstydliwego (1234-1292). Atrybucja taka pojawiła się już w monografii katedry krakowskiej pióra ks. bp. Ludwika Łętowskiego, który oparł ją na informacji zawartej w aktach wizytacji bp. Andrzeja Trzebickiego z $1670 \mathrm{r}$. Nie przeszkadzało to mu uznawać jednocześnie istnienia drugiego relikwiarza, $\mathrm{z}$ daru królowej Elżbiety Łokietkówny ${ }^{4}$. Tezę o dwóch następujących kolejno po sobie trumnach przyjął ks. Ignacy Polkowski. ${ }^{5}$ Ewa Śnieżyńska-Stolot przypisała fundację św. Kindze, datując relikwiarz znany z siedemnastowiecznego opisu na 2. poł. w. XIII ${ }^{6}$. Zdecydowanie też odrzuciła wysuwane przez innych badaczy sugestie co do możliwości sprawienia relikwiarza zarówno przez Elżbietę Łokietkównę, jak i św. królową Ja-

${ }^{4}$ Łę towski 1859, s. 6, 20, 91, 92.

${ }^{5}$ I. P o 1 k o w sk i, Szkic do katedry na Wawelu przed 450 laty, Kraków 1887, s. 7; P o 1 k o w sk i 1888, s. 32; za fundatorkę pierwotnego relikwiarza (zastapionego nowym w w. XIV) uznal św. Kingę również S. W in d a k i e w i c z, Dzieje Wawelu, Kraków 1925, s. 41.

${ }^{6}$ Śn i ézýn ska-S to lot 1972, s. 176-179. 
dwige, a to ze względu na dokument bp. Jana Grota wzmiankujący trumnę św. Stanisława już w 1336 r. ${ }^{7}$ Za św. Kingą opowiedział się jednoznacznie również Michał Rożek, który oprócz zapisu z r. 1670, przytoczył też przekazy o udziale księżnej w uroczystościach pokanonizacyjnych w Krakowie w 1254 r. i jej osobistym zaangażowaniu w przenoszenie relikwii św. Stanisława do nowej trum$n^{8}{ }^{8}$. Podobne stanowisko zajęli też: Alicja Karłowska-Kamzowaa ${ }^{9}$, Aleksandra Witkowska $^{10}$, Janusz S. Pasierb ${ }^{11}$, Wojciech Mischke ${ }^{12}$, Urszula Borkowska ${ }^{13}$.

Argumentacja wysuwana przez zwolenników wczesnej datacji trumny budzi szereg watpliwości. Co do fundamentalnej dla tej tezy zapiski w aktach wizytacyjnych katedry: Hanc $S^{\text {ta }}$ Cunegundis comparasse ex traditione antiqua fertur [podkr. K.J.C.] ${ }^{14}$, to trzeba zauważyć, że jej autor powoływał się jedynie na dawną (jak dawną?) tradycję. Przypomnieć należy, że w okresie, gdy powstała owa zapiska, kult Kingi wzmógł się w związku z podjęciem intensywnych starań o jej beatyfikację. Szczątki księżnej spoczywały wówczas w krakowskim kościele św. Andrzeja, a specjalnie wyznaczeni eksperci spisywali wszelkie świadectwa jej życia, czynów i pośmiertnej czci ${ }^{15}$. W tej atmosferze łatwo mogło dojść do przypisania jej fundacji dzieła, które dowodziło szczególnego nabożeństwa do św. Stanisława. We wcześniejszych przekazach dotyczących trumny brak jakiejkolwiek wzmianki o św. Kindze, natomiast pojawiaja się imiona Elżbiety Lokietkówny i św. Jadwigi Andegaweńskiej. Także przytoczony przez E. Śnieżyńską-Stolot dokument z 1336 r. dotyczący ofiar składanych super Tumbam seu sepulcrum eiusdem sancti [sc. Stanislai] wspomina je-

${ }^{7}$ Ś n i e ży ń s k a - S t o lot 1972, s. 176-177; większą powściagliwość w kwestii datowania zachował przywołując ten sam dokument J. P i e tr u s in s k i, Jak wygladał wizerunek kanonizacyjny św. Stanisława?, RHS XVII, 1988, s. 37, przyp. 10.

${ }^{8}$ R o że k 1979, s. 439-440; R o ż e k 1980, s. 68-69.

${ }^{9}$ A. K a r łow s k a-K a m z o w a, Wyobrażenia męczeństwa biskupa Stanistawa Szczepanowskiego (do potowy XVI w.), [w:] Interpretacja dzieła sztuki, Warszawa-Poznań 1976, s. 28.

${ }_{10} \mathrm{~A}$. W it k ow sk a, Kulty pqtnicze piętnastowiecznego Krakowa. $Z$ badań nad miejskg kultura religijna, Lublin 1984, s. 86-87.

${ }^{11}$ J. S. P a s i e r b, Życie, męka $i$ chwała św. Stanistawa w "Legendarium andegaweńskim" (BAV Vat. Lat. 8541), RHS XIX (1992), s. 62-63; J. S. P a s i e r b, M. J a n o c h a, Polonica artystyczne w zbiorach watykańskich, Warszawa [b.d.], s. 48-49.

${ }^{12}$ W. M i s c h k e, Relacje dziejów katedry wawelskiej $i$ kultu św. Stanistawa, [w:] Katedra krakowska w średniowieczu. Materiały Sesji Oddziału Krakowskiego Stowarzyszenia Historyków Sztuki. Kraków, kwiecieñ 1994, Kraków 1996, s. 156.

${ }^{13}$ U. B o rk ow s k a, Królewskie modlitewniki. Studium z kultury religijnej epoki Jagiellonów (XV i poczatek XVI wieku), Lublin 1999, s. 230.

${ }^{14}$ AKK, Akta wizytacji katedry krakowskiej bpa Andrzeja Trzebickiego, t. 1, sygn. Wiz. nr 51 (dalej: Wiz. Trzebickiego nr 51), s. 22.

${ }^{15}$ L. Kowals k i, S. F i sch e r, Żywot bt. Kingi i dzieje jej kultu, Tarnów 1992, s. 190-194, o kulcie sw. Kingi w Krakowie: s. 145-154. 
dynie ogólnie grób św. Stanisława, a nie konkretna, tę czy inną trumnę ${ }^{16} . \mathrm{Z}$ kolei, przekazy o udziale księżnej w wawelskich uroczystościach w r. 1254 nic nie mówią o samej fundacji relikwiarza, poza tym są one dość późnej daty (w. XV) i brak im potwierdzenia w najważniejszych trzynastowiecznych źródłach: $\dot{Z} y$ wocie i Cudach św. Stanisława ${ }^{17}$.

Jeszcze przed połowa w. XIX pojawiła się w literaturze starożytniczej i przewodnikowej informacja o ufundowaniu najstarszego relikwiarza przez królową Elżbietę Łokietkównę (1305-1380) ${ }^{18}$. Podał ją również L. Łętowski (nie odrzucając jednocześnie fundacji św. Kingi) ${ }^{19}$, August Essenwein ${ }^{20}$ oraz I. Polkowski, który uważał, że czternastowieczna trumna zastapiła pierwotna, wykonaną sumptem świątobliwej żony Bolesława Wstydliwego ${ }^{21}$. Powyżsi autorzy podawali również dokładną wagę trumny, co wskazuje, że swoje poglądy opierali na źródłach powstałych przed jej zniszczeniem ${ }^{22}$. Za dodatkowy argument shużył też zapis w aktach kapitulnych $\mathrm{z}$ r. 1633: veterem tumbam cineribus Sancti Stanislai ab Helizabetha regina constructum [podkr. K.J.C.], qua in sacristia est reposita ${ }^{23}$. Atrybucje tę przyjęli tylko nieliczni badacze w w. XX (Małgorzata Kosińska, ks. Ryszard Knapiński) ${ }^{24}$. Większość uznała ją za niedostatecznie udokumentowaną. Na przykład Jerzy Pietrusiński argumentował, że wzmianka z r. 1633 jest niewiarygodna, bowiem powstała w wyniku błędnego

${ }^{16}$ Tumba sancti Stanislai występuje też w dokumencie dotyczącym fundacji lampy wiecznej przez Jakuba z Tarnowa, datowanym 2 X 1399, Kodeks dyplomatyczny katedry krakowskiej siw. Wactawa, wyd. J. Piekosiński [Monumenta Medii Aevii Historica I, cz. 2], Cracoviae 1883, s. $241, \mathrm{nr}$ CCCCXLII.

${ }^{17}$ Krytyke tej tradycji przeprowadzili ostatnio L. K o wals k i, S. F is c h e r 1992, s. $63-$ -65 ; w w. XVII przekonanie o udziale księżnej w uroczystym podniesieniu relikwii św. Stanisława było mocno zakorzenione, skoro na złotym relikwiarzu jej czaszki z 1651 znalazła się scena przedstawiająca to wydarzenie; Ibidem, s. 124.

${ }^{18}$ A. G r a b o w s k i, Kraków i jego okolice, Kraków 1844 (wyd. IV), s. 166; J. M ą c z y ń s k i, Pamiatka z Krakowa. Opis tego miasta i jego okolic, cz. 2, Kraków 1845, s. 11.

${ }^{19}$ L. Ł ę to w s k i, Katalog biskupów, prałatów i kanoników krakowskich, t. I, Kraków 1852, s. $35 ;$ ie tow s k i 1859 , s. 6,20 .

${ }^{20}$ A. E s s e n w e i n, Die mittelalterlichen Kunstdenkmale der Stadt Krakau, Leipzig 1869, s. $29,78,172-173$.

${ }^{21}$ P ol k ow sk i 1887 , s. 7 ; P o l k ow ski, 1888, s. 32 . Elżbieta występuje jako fundatorka trumny również w popularnej literaturze dewocyjnej: Święte pamiątki Krakowa, Kraków 1883, s. 44.

${ }^{22} \mathrm{Pol}$ k ow s k i 1888, s. 32: Wage jej podaje X. biskup Lętowski na 362 grzywien srebra, nie podając źródta, zkq̨d tę wiadomość zaczerpnąt. Podana waga zgodna jest $\mathrm{z}$ danymi zawartymi w dzienniku ks. Jana Wielewickiego, o czym nižej.

${ }^{23}$ AKK, Act. Act. XIII, k. $163 \mathrm{v} . ;$ R o ż e k 1979, s. 441, uznał ten zapis za mało wiążący.

${ }^{24}$ M. Ko s i ń s k a, Zarys ikonografii św. Stanistawa na podstawie zabytków krakowskich do polowy XVI w., Sprawozdania Poznańskiego Towarzystwa Przyjaciół Nauk XVI, 1949, s. 99; R. K n a p iń sk i, Polscy święci w sztuce, [w:] Nasi święci. Polski stownik hagiograficzny, red. A. Witkowska, Poznań 1995, s. 673, przyp. 74 (później opowiedział się za fundacją Władysława Łokietka, zob. przyp. 35). 
rozumienia zapisu w Roczniku Świętokrzyskim, mówiącego o wykonaniu na polecenie Elżbiety Rakuszanki złotego relikwiarza na głowę św. Stanisława ${ }^{25}$.

Licznych zwolenników zyskała teza o fundacji trumny przez św. Jadwige Andegaweńską (1374-1399). Zaliczyć do nich należy Tadeusza Wojciechowskiego $^{26}$, Walerego Eliasza-Radzikowskiego ${ }^{27}$, Lucjana Rydla ${ }^{28}$, ks. Tadeusza Kruszyńskiego ${ }^{29}$, Stanisława Windakiewicza ${ }^{30}$, Adama Bochnaka ${ }^{31}$. Jerzy Pietrusiński powstrzymał się przed ostatecznym rozstrzygnięciem problemu, wyrażając wątpliwości co do fundacji św. Kingi, skłaniając się jednocześnie raczej ku św. Jadwidze ${ }^{32}$.

Podstawą dla tej hipotezy jest wzmianka w Roczniku Świętokrzyskim (kontynuacja): Hedvigis, quae jacet ante cimborium cooperuit argento deaurato sepulchrum eius [sc. sancti Stanislai] $]^{33}$. Niestety, nie wiemy, skąd autor, dokonujący tego, niejednoznacznego skądinąd zapisu, w początkach w. XVI wiedział o dużo wcześniejszej fundacji Jadwigi, dlatego musimy zachować wobec tego źródła rezerwę.

Niedawno sformułowana przez Małgorzatę Reiche-Kochanowską hipoteza o fundacji trumny przez Władysława Łokietka między r. 1320 a 1333, zasadza się na przekonaniu, że kult św. Stanisława jako patrona procesu zjednoczenia Polski po rozbiciu dzielnicowym odgrywał zasadniczą rolę w działaniach politycznych księcia kujawskiego. Trumna byłaby więc wyrazem jego wdzięczności za zdobycie korony i odnowienie Królestwa Polskiego w r. 1320. Hipotezę tę maja potwierdzać umieszczone na relikwiarzu wyobrażenia orłów odnoszące się do wątku ,zjednoczeniowego" w legendzie Świętego ${ }^{34}$. Argumentacja przedstawiona przez Autorke ma li tylko charakter spekulacji historycznej i nie znajduje potwierdzenia w przekazach dotyczących bezpośrednio wawelskiej trumny ${ }^{35}$.

${ }^{25}$ P ietrusiński 1988 , s. 37, przyp. 10.

${ }^{26}$ Wojciechowski 1900 , s. 88, 91-92.

${ }^{27}$ W. E li a s z-R a d zi k ow sk i, Kraków-Warszawa-Lublin-Lódź-Poznań-Wilno-Zakopane [b.d.], s. 368.

${ }^{28}$ L. R y d e 1, Przewodnik ludowy po katedrze wawelskiej, Kraków 1913, s. 1.

${ }^{29}$ T. K r u s z y ń s k i, Przewodnik po katedrze wawelskiej, skarbcu i grobach królewskich, Kraków 1924, s. 24.

${ }^{30} \mathrm{~W}$ indaki e wicz 1925 , s. 72.

${ }^{31}$ A. B ochnak 1957, s. $84,88-89$.

${ }^{32}$ P i e trusińs k i 1988, s. 37, przyp. 10; R o ż e k 1979, s. 441, przypuszczał, że św. Jadwiga pokryła ołtarz św. Stanisława blachami srebmymi lub odnowiła trumnę z fundacji św. Kingi.

${ }^{33}$ Monumenta Poloniae Historica III, Lwów 1878, s. 68, przyp. 1.

${ }^{34}$ M. Kochan owska-Re iche 1991, s. 36-39; także M. Kochanowska-Rei c h e, Ikonografia kanonizacyjna św. Stanistawa Biskapa, BHS XLIX (1987), s. 84, przyp. 25.

${ }^{35}$ Argumenty przytoczone przez Kochanowską-Reiche uznal za nieprzekonujące Mi s c h ke 1996, s. 161, przyp. 46; natomiast słuszność przyznał im R. Kn a p i ń s ki, Titulus ecclesiae. Ikonografia wezwań wspótczesnych kościołów katedralnych w Polsce, Warszawa 1999, s. 514, przyp. 25. 
Kwestię fundacji średniowiecznego relikwiarza można i trzeba dzisiaj rozpatrzyć na nowo. Szczęśliwie, kilka lat temu, opublikowano niezwykle cenne źródło, które pozwala na jej ostateczne, jak się wydaje, rozstrzygnięcie. Otóż, w pisanym przez ks. Jana Wielewickiego Dzienniku spraw domu zakonnego OO. Jezuitów u św. Barbary w Krakowie, napotykamy pod data 16 V 1631 r. informację o czynnościach podjętych w katedrze krakowskiej w związku z przeniesieniem relikwii św. Stanisława do nowej kaplicy wzniesionej sumptem biskupa krakowskiego Marcina Szyszkowskiego. Wiele uwagi autor zapisu poświęcił trumnie, w której czcigodne szczątki spoczywały: Quia cista argentea, in qua Reliquiae S. Stanislai conservabantur, antequam ad novum altare ac sacellum sumptuosissime in medio templi arcensis a Martino Szyskowski episcopo extructum transferenda esset, purgari debuit ab artificibus, ideo prius aperienda erat. Itaque 16-a istius mensis post vesperas praesentibus aliquot praelatis cum notario publico et ex nostris P. Friderico Szembek cum socio ac vicecancellario Regni [Thomae Zamoyski] cum sua coniuge aperta est Reliquiaeque in ea inventae delatae ad sacristiam et clausae ac sigillis munitae sunt, cista aurificibus relicta, ut mundaretur. Deprehenderant postea artifices plusquam 362 marcas argenti in eadem cista eiusque deaurationem triplo meliorem ista, quae iam solet esse, insuper tum compertum a regina Poloniae, matre Ludovici regis, fuisse comparatam plusquam a ducentis annis [podkr. K.J.C.] ${ }^{36}$. Wydarzenie to opisano także w aktach kapitulnych, ale bez tak szczegółowych informacji o samej trumnie jak w jezuickiej kronice: Explorata voluntate Illr ${ }^{m i}$ ac $R_{n} d^{m i}$ Dni Andreae Lipski Episcopi Cracovien(sis) viua vocis oraculo in discessu suo declarata necnon a V. Caplo die hodierna approbata tumba vetus argentea deaurata Sancti Stanislai Episcopi et Martyris ossa continens aperta est in presentia Ill ${ }^{m i}$ Dni Thomae Zamoyski Vicecancellarii Regni Capitanei Cracouien(sis) cum sua consorte et Adm Rndorum DD. Ioannis Foxii Archidiaconi Laurentii Starczewski Custodis Nicolai Szyskowski SRM. Secretarii Maioris Jacobi Ostrowski et Alberti Serebriski Canonicorum Cracouien(sium) quae a parte inferiori aperta continebat cistulam arculatam plumbeam funiculo canabeo grosso ligatam cum sigillo antiquo cuius reliquiae cereae apparebant Theca vero eius arculae clauiculis paruis seu filis ferreis in cistula vero plumbea insignis reliquia Sancti Stanislai serico duplici rubeo inuoluta et filo sericeo ligata quae formam brachy praesefert, quae quidem reliquia cum veneratione iterum in serico duplici rubeo, passamono ligata collocata est, et in eadem tumba plumbea, atq(ue) sigill(um) Rndi Dni Archidiaconi et Illr ${ }^{\text {mi }}$ Dni Vicecancellarii Regni, obsignata ad Sacristiam deportata est vt interim tumba Sancti Stanislai

${ }^{36}$ J. W i e l e w i c k i, Dziennik spraw domu zakonnego OO. Jezuitów u św. Barbary w Krakowie 1630-1639, t. 5, z maszynopisu J. Poplatka wyd. L. Grzebień, Kraków 1999, s. 97-98. 
maior expurgetur et renouetur. Actum in Capella SRM Rorant.(istarum) Anno et die vt supra $[16 \mathrm{~V} 1631]^{37}$.

W cytowanym tekście Wielewickiego przyciąga uwage dokonane bez jakichkolwiek zatrzeżeń przypisanie trumny Elżbiecie Lokietkównie. Jak wynika z kolejnej notatki z dnia 11 VII 1631 r., autor oparł się na solidnej podstawie: Eadem 11-a iulii cista argentea deaurata et expurgata collocata est in mausoleo Szyskoviano templi arcensis continens marcas argenti 352, in qua iterum inclusa erat alia argentea 40 marcarum cistula, aureum cylindrum immediate sacras S. Stanislai Reliquias continentem complectens, quam Thomas Zamoiski vicecancellarius Regni et notarius Poloniae Cracoviensisque generalis capitaneus pro plumbea arca, in qua antea Reliquiae erant, substituerat. Atque ita in universum cista praedicta maior cum minori 402 marcas argenti habebat, praeter aurum cylindri et deaurationem cistae extraordinariam. Aestimabantur praedicta haec eo tempore, quo ista scripsimus quattuordecim millibus nostrorum florenorum, sicuti et altare argenteum a Sigismundo I comparatum 18 millibus penes cistam tunc collocatum, sed postea ad maius altare translatum. Porro cistam hanc maiorem, ut ex eius inscriptione manifestum est, Elisabeth Hungariae et Poloniae regina, regis Ludovici Hungari mater, ante annos plusquam 200 S. Stanislao Cracoviensi episcopo miserat [podkr. K.J.C.] ${ }^{38}$. Powyższy zapis nie pozostawia watpliwości co do osoby fundatorki, na która wskazywał napis umieszczony wprost na trumnie. Wiarygodność przytoczonej relacji poświadczają liczne szczegóły, które mógł znać tylko naoczny świadek opisanych wydarzeń. On też musiał przy tej okazji odczytać inskrypcję fundacyjną. Można go identyfikować z jezuita, ks. Fryderykiem Szembekiem, wymienionym przez Wielewickiego wśród obecnych na Wawelu przy otwarciu relikwiarza ${ }^{39}$.

Pozostaje kwestią otwarta, dlaczego w r. 1670 nie wspomniano nic o napisie dotyczącym fundacji, skoro wizytator szczegółowo opisywał trumnę, a nawet podał jej wymiary. Można jedynie domniemywać, że inskrypcja była już wówczas nieczytelna albo całkowicie zniszczona. Niewykluczone, że znajdowała się ona kiedyś w kwaterze, na której personae nullae repraesentantur ${ }^{40}$.

Rozległa działalność Elżbiety Lokietkówny na polu fundacji artystycznych jest badaczom znana od dawna, w Polsce przede wszystkim dzięki opracowa-

${ }^{37}$ AKK, Act. Act. XIII, k. 7r.

${ }^{38}$ W i e lew ick i 1999, s. 104.

${ }^{39}$ Wiadomość o Elżbiecie jako fundatorce trumny w aktach z posiedzeń Kapituły z r. 1633 zaczerpnięta została $\mathrm{z}$ inskrypcji fundacyjnej, a nie powstała w wyniku błędnej interpretacji zapiski w Roczniku Świętokrzyskim, jak twierdził P i e t r u s i ń s k i 1988, s. 37, przyp. 10.

${ }^{40}$ AKK, Wiz. Trzebickiego (nr 52), s. 402. 
niom E. Śnieżyńskiej-Stolot ${ }^{41}$. Omówienie tego zagadnienia wykracza poza ramy niniejszego artykułu, trzeba jednak przypomnieć, że królowa hojnie obdarzała kościoły kosztownymi sprzętami i szatami liturgicznymi. Wiemy o wspaniałych darach złożonych w skarbcu bazyliki św. Piotra w czasie pielgrzymki do Rzymu. Liczne, złote i srebrne naczynia oraz sprzęty, rozdzieliła w testamencie pomiędzy różne świątynie ${ }^{42}$. Namacalnym dowodem wysokiego poziomu powstających w jej kręgu dzieł złotniczych jest ołtarzyk przypisywany warsztatom paryskim, datowany na lata $1320-1340$, przeznaczony prawdopodobnie dla kościoła klarysek w Starej Budzie (Nowy Jork, Metropolitan Museum $)^{43}$. O zaangażowaniu się królowej w patronat nad Kościołem w Polsce świadczą drewniane figurki jasełkowe opatrzone literą E pod koroną zachowane w klasztorze klarysek przy kościele św. Andrzeja w Krakowie ${ }^{44}$.

Zainteresowanie królowej św. Stanisławem poświadcza umieszczenie scen $\mathrm{z}$ jego żywota w słynnym Legendarium andegaweńskim (Biblioteka Watykańska, sygn. Vat. lat. 8541) ${ }^{45}$. Zajmujący się tym rękopisem badacze podnosili kwestię wpływu Elżbiety na jego program ikonograficzny i wprowadzenie do niego postaci krakowskiego męczennika ${ }^{46}$. $Z$ całą pewnością trumnę św. Stanisława można zaliczyć do najważniejszych fundacji królowej - tak pod względem ideowym (uczczenie głównego patrona Polski), artystycznym, jak i materialnym oraz finansowym.

Spróbujmy dokonać przybliżonej rekonstrukcji relikwiarza św. Stanisława, korzystając z dość szczegółowego opisu dokonanego w r. 1670 podczas wizytacji katedry krakowskiej. Co prawda, wykorzystywano go już w tym celu kilkakrotnie $^{47}$, ale wydaje się, że można dokonać na nowo jego poszerzonej interpretacji.

${ }^{41}$ E. Ś n i ż y ń s ka - S to 1 ot, Queen Elisabeth as a Patron of Architecture, „Acta Historiae Artium Academiae Scientiarum Hungaricae" XX (1974), s. 13-36; Idem, Ze studiów nad kulturq dworu wegierskiego królowej Elżbiety Lokietkówny, „Studia Historyczne” XX (1977), s. 181-190; Idem, Ikonografia królowej Elżbiety tokietkówny, BHS XXXIII (1977), s. 12-22; Idem, Odkrycie klasztoru klarysek i grobu Elżbiety Eokietkówny na Wegrzech, BHS XLI (1979), s. 21-22.

${ }^{42}$ S. A. S r o k a, Elżbieta Lokietkówna, Bydgoszcz 1999, s. 69-79.

${ }^{43} \mathrm{Nr}$ inw. 1962. 62. 96; K. S z c z e p k ow s k a - $\mathrm{Nal}$ i w a j e k, Relikwiarze średniowiecznej Europy od $I V$ do poczqtku XVI wieku. Geneza, treści, styl i techniki wykonania, Warszawa 1996, s. 178-183.

${ }_{44}$ Pax et Bonum. Skarby Klarysek krakowskich. Katalog wystawy, Krakow 1999, s. 80-81, poz. IV/10 (opr. A. Olszewski), il. XX-XXII.

${ }^{45} \mathrm{~F}$. L e v a r dy, Wegierskie legendarium andegaweńskie, Wrocław-Budapeszt 1978; K ochan owska-Reiche 1991, s. 39-47; P asierb 1992, s. 45-63; Pasierb, Jan ocha, s. $32-50$, il. II-XI.

${ }^{46}$ Śn i eży ńska - S to lot 1972 , s. 166.

${ }^{47}$ Śnieżyńska-Stolot 1972, s. 177-179; Rożek 1979, s. 440; Rożek 1980 , s. $68-69 ; \mathrm{Koch}$ anowska-Reiche 1991 , s. 33-36. 
Na początek przytoczmy pełny tekst źródłowy: tumba easdem Sacros Reliquias continens longitudinis circiter trium cubitorum latitudinis vero unius et alterius medii cubitorum in parte inferiori altitudinis trium circiter palmarum non pure argentea sed tantum tabulis seu laminis argenteis inauratis historiam gloriosi Martyris Sancti Stanislai Pontificis opere fusorio repraesentantibus omni ex parte circumducta et quidem a latere seu facie altaris sacelli exstant tabulae sex in prima a parte Euangelii Aquilae tres corpus Sancti Praesulis dissectu(m) in unum congerentes, in secunda personae sex, in tertia personae quinq(ue), in quarta personae duae in quinta personae tres vna Petrovini cum Sarcophago in sexta personae duae repaesentantur, a latere veri versus majorem chorum indem a parte inferiori exstant tabulae sex in quorum prima a parte Euangelii personae duae vna absq(ue) capite. in secunda persona vna altera in tumbecula, in tertia personae tres vna carens capite, in quarta personae duae, in quinta personae duae in sexta personae nullae repraesentantur. Item in eadem tumba a parte Euangelii exstat Signum Aquilae et personae quatuor ac columnae pyramidales tres, similiter a parte Epistolae exstat, Signum Aquilae et personae quinq(ue) ac similes columnae tres laminis argenteis inauratis obductae. a parte vero Superiori eiusdem tumbae summitas tenuior tabulas octodeum (!) continet, in quorum vnaquaq(ue) personae habitu Pontificali insignitae reperiuntur, in vertice vero eiusdem partis superioris exstant coronullae in nonnullis locis effractae ${ }^{48}$.

Niestety, nie zachował się żaden przekaz ikonograficzny ukazujacy prawdziwy wygląd średniowiecznej trumny. Wszystkie znane, przywoływane w literaturze wizerunki grobu św. Stanisława mają charakter fantastyczny. Znajdujemy je w scenie Uzdrowienia Piotra Wegra w Legendarium andegaweńskim ${ }^{49}$, a także, zdaniem E. Śnieżyńskiej-Stolot, w kwaterze ołtarza w Muzeum Sztuk Pięknych $w$ Budapeszcie ${ }^{50}$. Jedynym zgodnym $\mathrm{z}$ rzeczywistością rysem tych relikwiarzy jest ich ogólny ksztalt: prostokątnej skrzyni $z$ dwuspadowym wiekiem. Niektórzy badacze sugerowali, że realistyczne przedstawienie trumny Męczennika znajduje się na obrazie w kościele Dominikanów w Krakowie (wiązany z Tomaszem Dolabellą, datowany na pocz. w. XVII) ${ }^{51}$, gdzie między innymi ukazano scenę translacji ciała Męczennika ze Skałki na Wawel ${ }^{52}$. Nie-

\footnotetext{
${ }^{48}$ AKK, Wiz. Trzebickiego (nr 52), s. 401-402.

${ }^{49}$ Śn i eży ńska-S tol ot 1972, s. 163-166, il. 2; Pas ierb 1992, s. 60-62, il. 8; P asierb, J a n o ch a, s. 47-49, il. III, XI.

${ }^{50}$ Śn i eży ńs ka-Stolot 1972, s. 170-171, il. 4.

${ }^{51}$ Katalog Zabytków Sztuki w Polsce, t. IV: Miasto Kraków, cz. 3: Kościoły i klasztory Śródmieścia 2, Warszawa 1978, s. 120, il. 368.

${ }^{52}$ R ożek 1979, s. 440, przyp. 42; M is chke 1996, s. 156, identyfikuje mylnie te scene jako Pogrzeb św. Stanisława, tymczasem z pewnością jest to wyobraźenie translacji ze Skałki;
} 
siony w procesji skrzyniowy relikwiarz został scharakteryzowany bardzo sumarycznie, pozbawiony jest całkowicie dekoracji z wyjątkiem krzyża na krótszym boku, co uniemożliwia identyfikowanie go ze znaną z opisów trumną ${ }^{53}$. Dla porządku odnotować wypada zupełnie nieuzasadnione dopatrywanie się trumny św. Stanisława przez T. Wojciechowskiego na miniaturze przedstawiającej Koronację króla w pontyfikale Erazma Ciołka ${ }^{54}$.

Wymiary trumny podane w r. 1670, pozwalają wyobrazić sobie jej wielkość. Zatem, długość wynosiła 3 łokcie, szerokość 11/2 lokcia, wysokość części dolnej, a więc samej skrzyni bez wieka, $3 \mathrm{dłonie}^{55}$. Jeśli chodzi o wiarygodność wymiarów podanych przez autora opisu dokonanego w czasie wizytacji, to można ja sprawdzić porównując zawarte w tym samym źródle dane do ołtarza (retabulum) w kaplicy Zygmuntowskiej. Miał on według opisu wizytacyjnego ok. 4 łokci wysokości $(234,4 \mathrm{~cm})$ i ok. 3 tokci szerokości $(175,8 \mathrm{~cm})$. Jego rzeczywiste wymiary wynoszą $247,4 \times 174 \mathrm{~cm}$. Różnice są więc niewielkie (odpowiednio $13,1 \mathrm{~cm}$ oraz $1,8 \mathrm{~cm}$ ), co dowodzi wysokiej wiarygodności przekazu źródłowego.

Przeliczając historyczne wymiary relikwiarza na współczesne jednostki ${ }^{56}$, uzyskujemy obraz prostopadłościennej skrzyni o wymiarach (przybliżonych) $175,8 \times 87,9 \times 43,95 \mathrm{~cm}$. Otwarty pozostaje problem ustalenia wysokości dwuspadowego wieka. $Z$ dużym prawdopodobieństwem można przyjąć, że mieściła się ona w granicach $2 / 3$ do 1 wysokości korpusu $(29,3$ do $43,95 \mathrm{~cm})$. Wygląda na to, że konstruując relikwiarz użyto modułu liczącego 3 dłonie $(43,95 \mathrm{~cm})$, odpowiadającego wysokości skrzyni bez wieka. Mnożąc go przez 2 otrzymuje-

scenerię wydarzenia stanowi droga wiodąca na Wawel, ujęta od góry murem obronnym wzdłuż pn. frontu zabudowań zamkowych oraz murem dolnym, pomiędzy domem na końcu ul. Kanoniczej (z lewej) a Bramą Dolną zamku (z prawej).

${ }^{33}$ Osobnym problemem jest interpretacja obrazu dominikańskiego. Niezwykła jest jego kompozycja: scenę Świadczenia przed królem otaczają epizody z legendy św. Stanisława ujęte w profilowane obramienia (prostokątne, z półkolistymi zamknięciami krótszych boków) z ozdobnymi przewiązkami, imitujące jakby ramy stolarskiej roboty. Niezrozumiałe jest też ucięcie ram po bokach obrazu, tak jakby ten został wtórnie pomniejszony. Szczególne wyeksponowanie Translacji ciała św. Stanisława (pośrodku, pod sceną główna) może sugerować, że powodem powstania płótna było ożywienie zainteresowania Świętym w związku z budową okazałej konfesji na Wawelu i wieńczaca ją uroczysta translacja relikwii 10 VI 1631 (relacja o tym wydarzeniu: Wi elewicki 1999, s. 100-101).

${ }^{54}$ Woj ciechowski 1900 , s. $92-93$.

${ }^{55}$ AKK, Wiz. Trzebickiego, (nr 52), s. 401: tumba [...] longitudinis circiter trium cubitorum latitudinis vero unius et alterius medii cubitorum in parte inferiori altitudinis trium circiter palmarum. Pewne watpliwości budzi sprawa wysokości trumny, ponieważ określenic: in parte inferiori odnieść można zarówno do poprzedzającej go szerokości lub do następującej po nim wysokości. Trzeba przyjąć jednak drugą możliwość, ponieważ w innym przypadku wysokość całkowita trumny byłaby niewiarygodnie mała.

${ }^{56}$ Według J. S z y m a ń s k i, Nauki pomocnicze historii, Warszawa 2002, s. 163. 
my jej szerokość $(43,95 \times 2=87,9 \mathrm{~cm})$, a z kolei przez 4 - dhugość $(43,95 \times 4=$ $175,8 \mathrm{~cm}$ ). Tak więc, proporcje korpusu opisuje stosunek liczb: 4:2:1. Przyjmując, że wysokość wieka odpowiadała wysokości korpusu, otrzymujemy natomiast stosunek 4:2:2 (po uproszczeniu 2:1:1). Szczególną uwagę zwraca znaczna szerokość trumny stanowiąca aż połowę jej długości.

Źródła podaja, że relikwiarz wykonano $\mathrm{z}$ drewna, na które nałożono dekorację srebrną wykonaną techniką odlewu (opere fusorio) ${ }^{57}$. Całość pokrywało złocenie. W opisie z 1670 r. zaznaczono, że ma on summitas tenuior, co oznacza, że zdobienia na wieku były mniej plastyczne niż na bokach. Być może wykonano jej też inną technika, np. trybowania. Na dłuższych bokach rozmieszczono po sześć kwater mieszczących sceny z żywota św. Stanisława, rozdzielonych pewnie kolumienkami (na to wskazuje zapis z r. 1638) ${ }^{58}$, górą zamkniętych może łukami (ostrymi?, w ośli grzbiet?). W opisie zaznaczono, że przy krótszych bokach były umieszczone columnae pyramidales tres ${ }^{59}$. Cóż może znaczyć to określenie? Najsłuszniejsze wydaje się tłumaczenie owych „kolumn piramidalnych" jako uskokowo zwężających się ku górze przypór. Nie można ich przecież, ze względu na czas powstania relikwiarza, uznać za nowożytne obeliski. Przy każdym boku znajdowały się trzy przypory. Dwie z nich musiały akcentować narożniki, natomiast trzecia, umieszczona pośrodku, dzieliła bok na dwa pola. Obie połacie wieka podzielono (kolumienkami?) na dziewięć kwater, w których znalazło się osiemnaście postaci świętych biskupów. Trójkątne szczyty zamykające wieko na krótszych bokach posłużyły do ukazania postaci orłów. Grzbiet wieka („kalenicę”) wieńczyła ażurowa koronka.

Jakkolwiek szczegóły powyższej rekonstrukcji mają charakter hipotetyczny, to określenie zasadniczego kształtu trumny św. Stanisława nie nastręcza trudności. Należał on do popularnego w okresie średniowiecza typu relikwiarzy w kształcie skrzyni nakrytej dwuspadowym wiekiem. Rozpowszechniły się one szczególnie w Nadrenii i rejonie Mozy w XII i XIII w. Poświęcono im tak liczne opracowania ogólne i szczegółowe, że ich przegląd wymagałby osobnego artykuł $^{60}$. Wykonywano je ze złoconej miedzi, srebra, a nawet złota, i co szczególnie charakterystyczne, dekorowano filigranem, kameryzacją oraz plakietkami z emalii żłobkowej. $\mathrm{Z}$ racji stosowania do artykulacji kolumienek, pi-

${ }^{57}$ AKK, Wiz. Trzebickiego (nr 52), s. 401; w AKM, Wiz. Zadzika 1638 (AVCap 34), k. 90v. mowa o brakach postaci fusilis argenti.

${ }_{58}$ AKM, Wiz. Zadzika 1638 (AVCap 43), k. 90v.: Tumba [...] habet multos in argento defectus, m.in. particulae multo aliquot columellarum [desunt].

${ }^{59}$ AKK, Wiz. Trzebickiego (nr 52), s. 402.

${ }^{60}$ Ostatnio na ten temat A. L e g n e r, Kölner Heilige und Heiligtümer. Ein Jahrtausend europäischer Reliquienkultur, Köln 2003 (tam obszerny spis wcześniejszej literatury); w polskiej literaturze omówiła to zagadnienie Szczepkowska-Naliwajek 1996, s. 139-146. 
lastrów, przypór oraz arkadowych podziałów upodabniały się one wyraźnie do monumentalnych kościołów. Na dłuższym boku umieszczano zwykle zwieńczony szczytem fronton, który przypominał transept. W arkadach ustawiano najczęściej figurki Chrystusa, Marii, apostołów i świętych. Wieko służyło zazwyczaj do rozwinięcia dziejów tego świętego, którego szczątki spoczywały wewnątrz.

W w. XII powstał cały szereg relikwiarzy przeznaczonych dla kościołów kolońskich: Trzech Króli w katedrze (ok. 1165-1225) ${ }^{61}$, św. Maurinusa (ok. $1170)^{62}$ i św. Albanusa (ok. 1186) ${ }^{63}$ w kościele św. Pantaleona, św. Seweryna w kościele pod jego wezwaniem (znany z obrazów 1499-1501) ${ }^{64}$, św. Eteriusza (ok. 1170) w kościele św. Urszuli ${ }^{65}$, św. Heriberta (3. ćw. w. XII) w KoloniiDeutz ${ }^{66}$. Poza Kolonią podobne przykłady znajdujemy np. w Akwizgranie (Karola Wielkiego, 1182-1215) ${ }^{67}$, w katedrze w Xanten (św. Wiktora, 1129-1150, później przekształcony ${ }^{68}$ lub $w$ kościele opackim św. Michała w Siegburgu (św. Annona, ok. 1183)

W kolejnym stuleciu relikwiarze skrzyniowe nie straciły na popularności, jednocześnie pojawiły się w nich stopniowo formy gotyckie. Są wśród nich takie arcydzieła jak relikwiarze Marii w Akwizgranie $(1220-1238)^{70}$ oraz św. Elżbiety w katedrze w Marburgu (1235-1243) ${ }^{71}$. Ten ostatni powinien zwrócić szczególnie naszą uwage, oglądała go bowiem w czasie swej pielgrzymki w roku 1357 Elżbieta Lokietkówna. Mógł więc on stanowić inspirację do fundacji relikwiarza św. Stanisława. Należy też wymienić trumny śś. Feliksa i Adaukta w kościele św. Apostołów w Kolonii (ukończony w r. 1225, znany z rysunku) ${ }^{72}$, św. Firmina w katedrze w Amiens (poł. w. XIII) ${ }^{73}$, św. Romana w Rouen (k. w. XIII) ${ }^{74}$,

${ }^{61}$ L e gne r 2003, s. 108-114, il. 57.

${ }^{62} \mathrm{~L}$ e g n er 2003, s. 166-167, il. 107.

${ }^{63} \mathrm{~L}$ e g n e r 2003, s. 164-166, il. 105-106.

${ }^{64} \mathrm{~L}$ e g n e r 2003, s. 155-156, il. 92-94.

${ }^{65} \mathrm{~L}$ e g n e r 2003, s. 210 , il. 143.

${ }^{66} \mathrm{~L}$ e g ner 2003, s. 265, il. 193-194.

${ }^{67}$ E. G. G ri m m e, Der Aachener Domschatz, Düsseldorf 1973, s. 66-69, poz. 44, tabl. X, il. 52-56; H. Le p i e, G. M in ke n berg, Die Schatzkammer des Aachener Domes, Aachen 1995 , s. $12-13$.

${ }^{68}$ U. Grote, Der Schatz von St. Viktor. Mittelalterliche Kosbarkeiten aus dem Xantener Dom, Regensburg 1998, s. 23-30, 74-80, poz. 3 .

${ }^{69}$ L e g n e r 2003, s. 281, il. 209.

${ }^{70} \mathrm{Grimm}$ e 1973 , s. $71-73$, poz. 48 , il. 59-62.

${ }^{71}$ E. L e p p in, Die Elisabethkirche in Marburg, Marburg 1983, s. 36-40.

${ }^{72} \mathrm{~L}$ e g n er 2003, s. 174, il. 113.

${ }^{73}$ Les Tresors des Eglises de France, Paris 1965, s. 28-29, poz. 59, il. 89.

${ }^{74}$ Les Tresors..., s. 108-109, poz. 210, i1. 112. 
św. Tauryna w Evreux (1240-1255) ${ }^{75}$, św. Gertrudy w Nivelles ${ }^{76}$, a z mniej znanych i skromniejszych, dwie skrzynie relikwiarzowe w Bouillac (w. XIII) ${ }^{77}$.

Reservacula wielkich rozmiarów były wzorem dla realizacji w niewielkiej skali, jak w przypadku relikwiarza w Reiningue (w. XII) ${ }^{78}$, czy dla masowo wytwarzanych relikwiarzyków limuzyjskich.

Jeśli chodzi o treści ideowe zawarte w tego rodzaju dziełach, to ogólnie można stwierdzić, że miniaturowe budowle, bardzo często z postaciami Chrystusa, Marii i świętych, symbolizowały Niebieską Jerozolimę. Trzeba zwrócić uwagę również na ich podobieństwo do wyobrażeń Arki Przymierza. O tym, że nie jest ono przypadkowe, doskonale świadczy napis umieszczony na relikwiarzu św. Wiktora w Xanten: FEDERIS ARCA TVLIT PATRIBVS SIGNACVLA TANTVM HEC TAM REM QVAM SPEM POPVLO FERT TEMPORIS OMNIS $^{79}$.

Ze względu na czas powstania trumny św. Stanisława - 2. poł. w. XIV właściwy kontekst dla niej stanowią relikwiarze z okresu późnego średniowiecza. Niestety, zniszczeniu uległy dzieła, które mogły bezpośrednio wpłynąć na trumnę fundacji Elżbiety Łokietkówny. Mowa przede wszystkim o wspaniałym relikwiarzu św. Wacława (1358) w katedrze św. Wita w Pradze, ufundowanym przez cesarza Karola IV. Znamy go tylko $\mathrm{z}$ opisów, ponieważ został zniszczony w okresie wojen husyckich ${ }^{80} Z$ końca w. XIV pochodzi relikwiarz św. Sebalda w kościele jego imienia w Norymberdze (Norymberga, Fritz Habeltsheimer St., $1391-1397)^{81}$. Jego boki i wieko pokrywa w całości rombowa kratownica wypełniona herbami. To chrakterystyczne norymberskie rozwiązanie powtórzono później w skrzyni przeznaczonej do przechowywania głównych relikwii Rzeszy, dawniej w tamtejszym kościele Mariackim, obecnie w Germanisches Nationalmuseum (Norymberga, wyk. Peter Ratzko, Hans Schesslitzer, 1438-1440) ${ }^{82}$. Inne zachowane reservacula datowane są na w. XV. Najpierw trzeba wspomnieć relikwiarz śś. Kosmy i Damiana w kościele św. Michała w Monachium

${ }^{75}$ Les Tresors, s. 111-113, poz. 217, il. 113.

${ }^{76}$ Schatz aus den Trümmern. Der Silberschrein von Nivelles und die europäische Hochgotik. Eine Ausstellung des Schnütgen-Museums, Köln vom 24. November 1995 bis 11. Februar 1996, Köln 1995.

${ }^{77}$ Les Tresors, s. 281, poz. 520, il. 111 (relikwiarz Ukrzyżowania), s. 281-282, poz. 521, il. 110 (relikwiarz Chrystusa Prawodawcy).

${ }^{78}$ Les Tresors, s. 455-456, poz. 862, il. 87.

${ }^{79}$ Grote 1998 , s. $76,78$.

${ }^{80}$ P. O brazová, J. V l k, Svatý kniže Václav, Praha-Litomyšl 1994, s. 166; S z c z e pkowska-N al i wajek 1996, s. 225-226, przyp. 117

${ }^{81} \mathrm{H}$. K o h 1 h a u s e n, Nürnberger Goldschmiedekunst des Mittelalters und der Dürerzeit 1240 bis 1540, Berlin 1968, s. 93-94, poz. 167, il. 156, 157.

${ }^{82} \mathrm{~K}$ o h 1 h a u sen 1968 , s. $95-97$, poz. 169 , il. 159-161. 
(Brema, pocz. w. XV) ${ }^{83}$. Jego narożniki zaakcentowane są bardzo wydatnymi przyporami, co przypomina rozwiązanie zastosowane prawdopodobnie $\mathbf{w}$ trumnie krakowskiej.

Kolejne relikwiarze skrzyniowe reprezentuja już formy późnego gotyku, nie można więc ich zestawiać $\mathrm{z}$ wawelskim, ale dla dopełnienia obrazu warto o nich wspomnieć. Przywołać można np. relikwiarz św. Reginy w Rhynern (ukończony 1457$)^{84}$ oraz św. Fortunaty w Reichenau-Mittelzell (Konstancja?, ok. 1470/80). ${ }^{85}$ Imponującym okazem późnogotyckiego złotnictwa jest skrzynia ze szczątkami śś. Gerwazego i Protazego w Breisach (St. Stephan), wykonana w 1496 r. w Strasburgu. ${ }^{86}$ Szereg innych relikwiarzy skrzyniowych, rzeczywistych bądź imaginowanych, ukazuje ikonografia. Można tu wspomnieć choćby relikwiarz Agilolfusa w Kolonii (St. Mariengraden) ${ }^{87}$ czy trumnę przedstawioną na obrazie Ekshumacja św. Huberta (Rogier van der Veyden z warsztatem, ok. 1440) w National Gallery w Londynie ${ }^{88}$. Jako przykład odmiany skrzyniowego reservaculum $\mathrm{z}$ reliefową postacią świętego na wieku można przytoczyć relikwiarz św. Arsacjusza, ustawiony na ołtarzu przy lektorium (Kreuzaltar) w kościele Mariackim w Monachium ${ }^{89}$.

Kończąc ten przegląd warto dodać, że architektoniczne relikwiarze imitujące gotyckie lub renesansowe budowle występowały i w czasach nowożytnych. Przykładem mogą być niewielkich rozmiarów reservacula w Saint-Nic (1578) ${ }^{90}$ i La Martyre (w. XVI) ${ }^{91}$. Podobnie w Nadrenii wskazać można relikwiarz Machabeuszy w kolońskim kościele św. Andrzeja (Peter Hanemann, Kolonia, $1520 / 27)^{92}$. Szczególnym przykładem nowożytnej kontynuacji tradycji nadreńskich relikwiarzy skrzyniowych jest relikwiarz św. Liboriusza w katedrze w Paderborn (Hans Hamburg, Krakko, 1627). Zachowano w nim zarówno kształt skrzyni nakrytej dwuspadowym dachem, jak i podziały architektoniczne, choć unowocześniono je wprowadzając porządki all'antica. Również postać tronującej Marii z Dzieciątkiem, postacie świętych oraz wizerunek św. Liboriusza

${ }^{83} \mathrm{~K}$ oh $\mathrm{l}$ h a u sen 1968 , s. $253-254$, il. $481,485$.

${ }^{84}$ J. M. Fritz, Goldschmiedekunst der Gotik in Mitteleuropa, München 1982, s. 252, il. $467,468$.

${ }^{85}$ Fritz 1982 , s. 281 , il. 681.

${ }^{86}$ Fritz 1982 , s. 283 , il. $705-707$.

${ }^{87}$ Le g ner 2003, s. 116, il. 61.

${ }^{88} \mathrm{Nr}$ inw. NG 783 .

${ }^{89} \mathrm{Ch}$. K a rn e h m, Die Münchner Frauenkirche. Erstausstattung und barocke Umgestaltung, [Miscellanea Bavarica Monacensia. Dissertationen zur Bayerischen Landes- und Münchner Stadtgeschichte, hrsg. von K. Bosl, R. Bauer, Heft 113], München 1984, s. 42-45.

${ }^{00}$ Les Tresors, s. 170-171, poz. 318, il. 195.

${ }^{91}$ Les Tresors, s. 164, poz. 305, il. 194.

${ }^{92}$ Fritz 1982, s. 312-313, il. 911, 913; Legner 2003, s. 230-233, il. 161-162. 
nawiązują do wystroju wcześniejszego, zniszczonego relikwiarza średniowiecznego.

Jak widać, typ skrzyniowego relikwiarza charakterystyczny w XII i XIII w. głównie dla Nadrenii i rejonu Mozy, później rozpowszechnił się w całej Europie. Tak więc, pojawiające się $w$ literaturze przypuszczenie o pochodzeniu wawelskiej trumny św. Stanisława z kręgu nadreńskiego nie wydaje się uzasadnione. W sensie genetycznym wywodziła się ona oczywiście ze słynnych dzieł nadreńskich i mozańskich złotników, ale powstała zapewne w Środkowej Europie. Niewykluczone, że było to któreś z głównych centrów złotniczych Węgier albo Polski (Buda?, Kraków?).

Osobnego omówienia wymagają figury czterech aniołów, które według źródeł stanowiły podstawę dla trumny z relikwiami św. Stanisława. W r. 1602 wizytator zapisał: tumba (...) innixa quatuor Angelorum statuis ${ }^{93}$. W związu $\mathrm{z}$ budową nowej kaplicy św. Stanisława $\mathrm{z}$ fundacji bp. Marcina Szyszkowskiego, Kapituła na posiedzeniu 7 II 1628 debatowała: De sepulchro S. Stanislai omni cum decentia ornand(um) praecipue de Angelis sustentantibus tumbam S. Stanislai noua forma decentum collocand(um) similiter tumbam decentiori modo si et in quantum adornari poterit ad vlteriorem deliberationem suspendendum decreuerunt ${ }^{44}$. Jakie ustalenia ostatecznie przyjęto, nie wiemy. Prawdopodobnie ograniczono się tylko do naprawy figur, skoro w r. 1630 zapłacono 15 gr Stolarzowi od zwiertowania (?) ręku angiolow kliienie ich. ktorzy trymaia tumbe S. Stanisz. oraz 6 gr Za Cwieki do tych angiolow ${ }^{95}$.

Nie posiadamy żadnych danych, by określić datę powstania tych rzeźb. Jeśli przyjać, że powstały równocześnie $z$ trumną fundowaną przez Elżbietę Lokietkównę, mielibyśmy do czynienia $\mathrm{z}$ dość wyjątkowym przykładem ekspozycji średniowiecznego relikwiarza. Zachowane podobne dzieła oraz przekazy ikonograficzne pouczają bowiem, że skrzynie relikwiarzowe spoczywały zazwyczaj bezpośrednio na mensie ołtarzowej, czasem na filarkach lub kolumienkach. Wyjątkiem była znana z ikonografii trumna św. Deokara, dawniej w kościele św. Wawrzyńca w Norymberdze (wyk. 1437 w miejsce wcześniejszej z 1316). W jej narożnikach u podstawy znajdowały się niewielkich rozmiarów figurki klęczących aniołków ze złoconej miedzi ${ }^{96}$. Anielskie postacie flankujące

${ }^{93}$ AKK, Wiz. Maciejowskiego (nr 20), s. 12; podobnie Inwentarz 1620 (I-81), s. 19: Tumba [...] quatuor angelor(um) statuis innixa. Niektóre przekazy mówią o sześciu aniołach, co należy uznać za pomyłkę, Przewodnik abo kościołów krakowskich opisanie wydany w 1603, wstęp i oprac. J. Kiliańczyk-Zięba, Kraków 2002, s. 80: $w$ trunnie $w$ śrebro oprawionej, którq sześć anjolów także oprawionych śrebrem trzyma.

${ }^{94}$ AKK, Act. Act. XII, k. 253r.

${ }_{95}$ AKK, Lib. fabr. 2, k. 115 r.

${ }^{96} \mathrm{~K}$ o h l h a u sen 1968 , s. $83,94-95$, poz. 168 , il. 158. 
trumnę św. Arsacjusza z 1496 ukazują widoki wnętrza kościoła Mariackiego w Monachium (Nikolaus Solis, 1568$)^{97}$. Są to jedyne znane autorowi przykłady rozwiązania podobnego (lecz nie identycznego) do wawelskiego. Nie można również wykluczyć, że figury w katedrze były późniejszym dodatkiem do czternastowiecznej trumny. Mogły zostać wprowadzone na przykład w r. 1512, gdy ustawiono na ołtarzu nowe retabulum fundacji Zygmunta I i zaistniała konieczność wywyższenia trumny tak, by była widoczna spoza niego. Wobec milczenia źródeł problem ten pozostawić musimy bez rozwiązania.

Drobiazgowe wyliczenie w aktach wizytacyjnych bp. A. Trzebickiego liczby postaci występujących $\mathrm{w}$ poszczególnych kwaterach sarkofagu skłania do podjęcia próby identyfikacji przedstawionych tam $\operatorname{scen}^{98}$. Rekonstrukcji ikonograficznego programu relikwiarza dokonała $\mathrm{M}$. Kochanowska-Reiche posiłkując się przy tym głównie ilustracjami w Legendarium andegaweńskim ${ }^{99}$. Niestety, dokonany przez nią wykład treści przedstawień nie przekonuje. Przede wszystkim, wiedza o liczbie postaci w scenach nie może wystarczyć do określenia treści, tym bardziej, że opis nie uwzględnia dziewiętnastu postaci brakujących już w 1638 r. ${ }^{100}$ Bez zastrzeżeń można rozpoznać kwatery ze Strzeżeniem ciała św. Stanistawa przez orly (od frontu pierwsza z lewej: Aquilae tres corpus Sancti Praesulis dissectu[m] in unum congerentes) oraz Wskrzeszeniem Piotrowina (tamże, pierwsza od prawej: personae tres vna Petrovini cum Sarcophago). Do rozpoznania treści kwatery, w której persona vna altera in tumbecula, brak dostatecznych podstaw - być może chodzi o jeden z cudów świętego (wskrzeszenie zmarlego? ${ }^{101}$. Nie wiemy czy sceny ułożone były zgodnie z chronologia. Układ zasstosowany w późniejszej, barokowej trumnie, niezgodny $\mathrm{z}$ następstwem czasu, każe zachować w tej kwestii ostrożność. Zakładajacc, że narracja powinna się zaczynać na ważniejszej, przedniej stronie trumny (albo od lewej albo od prawej strony), to powinny się tam znaleźć początkowe epizody historii, np. Konsekracja biskupia Stanisłowa (taka scenę wprowadza do rekonstrukcji Kochanowska-Reiche), Kupno wsi czy Swiadczenie przed królem, a nie - jak poświadcza przywołany opis - późniejsze wydarzenia: Wskrzeszenie

${ }^{97}$ Ch. Karnehm 1984, s. 42-43, il. 1-2. Według Autorki anioły były zwiazane nie z trumna, a z kolumnami podtrzymującymi zasłony ołtarzowe; takiej interpretacji nie potwierdza jednoznacznie analiza ikonografii, wątpliwości mogłyby rozwiać źródła opisowe.

${ }^{98} \mathrm{~W} 1620$ r. zamierzano po raz pierwszy dokładnie opisać poszczególne sceny na bokach, ale niestety, inwentaryzator odłożył to zadanie na później i nigdy go nie zrealizował - AKK, Inwentarz 1620 (I-81), s. 19.

${ }^{99} \mathrm{~K}$ ochanowska-Reiche 1991, s. 33-36.

${ }^{100}$ AKM, Wiz. Zadzika 1638 (AVCap 34), k. 90v.

${ }^{101}$ Jako wskrzeszenie zmarłego przez św. Stanisława odczytała tę scenę Śnieżyńska-Stolot 1972, s. 179. 
Piotrowina lub Strzeżenie ciala przez orły. Nie można też wykluczyć, że niektóre przedstawienia zostały rozdzielone pomiędzy sąsiadujące kwatery. $\mathrm{Na}$ takie rozwiązanie kompozycyjne może wskazywać niespotykanie duża liczba kwater - szesnaście (licząc łącznie $z$ tą, na której nie było postaci), a więc więcej niż w jakimkolwiek znanym cyklu z legendy św. Stanisława. Wystarczy przypomnieć, że w najobszerniejszej redakcji, na trumnie z lat 1669-1671, mieści się dwanaście scen.

Co się tyczy postaci osiemnastu biskupów umieszczonych na wieku relikwiarza, można jedynie sugerować, że były to przedstawienia idealnych świętych hierarchów Kościoła, którzy tak jak św. Stanisław dostąpili chwały ołtarzy. W podobny sposób należy interpretować figurki biskupów umieszczone na relikwiarzu głowy Męczennika, fundowanym w 2. ćw. w. XV przez królową Zofię Holszańską (tam ukazano je na przemian $\mathrm{z}$ postaciami aniołów) ${ }^{102}$.

Ostatnim zagadnieniem godnym poruszenia jest interpretacja orłów znajdujących się na krótszych bokach relikwiarza, zapewne w trójkątnych szczytach zamykających dwuspadowe wieko. Czy te signa aquilae to herby fundatorki, czy atrybuty św. Stanisława znane już z jego najstarszej, trzynastowiecznej ikonografii musi pozostać nierozstrzygnięte, choć druga ewentualność wydaje się bardziej prawdopodobna. ${ }^{103}$

Dopełnienia wymagają jeszcze dzieje gotyckiej trumny. Przypomnieć więc wypada, że od r. 1633, gdy Władysław IV ofiarował w imieniu swego ojca wspaniały nowy relikwiarz wykonany w Augsburgu, decyzją Kapituły z 10 II 1634 r. wystawiono ją w kaplicy śś. Piotra i Pawła, a więc w pobliżu wskazywanego przez tradycję miejsca pierwotnego pochówku św. Stanisława: Cum pietate Seren(issimi) olim Sigismundi Terty Regis Poloniae in cappella Diui Stanislai noua tumba pretiosa sit posita vti supra in Actis capitularibus Anni M.DCXXXIII die vero XXVI Mensis Marty est annotatum ideo veterem tumbam cineribus Sancti Stanislai ab Helisabetha Regina constructam quae in Sacristia est reposita pro deuotione fidelium supra lapideum Sancti Stanislai sepulchru(m) interim ad suum beneplacitum collocari debere Rndi DD Capitulum decreuerunt ita vt intus cratibus munita sit et sub Vicecustodis claue asseruetur in eaq(ue) reponatur cubitalis Sancti Stanislai reliquia qua hactenus in eodem lapideo sepulchro asseruabatur, tabula vero in crate ibidem exterius assignatur cum hac inscriptione Vetus Diui Stanislai Sepulchrum ${ }^{104}$. Nadano jej też nową

102 Wawel 1000-2000. Wystawa Jubileuszowa, t. 2: Skarby archidiecezji krakowskiej, s. 135-136, poz. II/100 (oprac. G. Regulska), il. 522.

${ }^{103}$ Określenie signa, a nie stosowanego zwykle dla opisu herbów arma nie pozwala na jednoznaczną interpretację. O herbach używanych przez Elżbietę Rakuszankę ostatnio: A. J a w o r s k a, Orzet Biały herb państwa polskiego, Warszawa 2003, s. 82-87.

${ }^{104}$ AKK, Act. Act. XIII, k. 163v.; P o 1 k ow s k i 1888, s. 33; W oj c i e ch ow sk i 1900 , s. 88; R o ż k 1979, s. 447-448; R o ż k k 1980, s. 248, przyp. 39. 
funkcję - służyła odtąd do przechowywania relikwiarza ręki Świętego, która dotąd spoczywała w specjalnej szafce zamykanej srebrną tablicą ${ }^{105}$. Zachowanie starej trumny wynikało bez watpienia nie tylko z przyczyn praktycznych, ale i z szacunku dla niej jako relikwii per contactum. Postapiono zatem podobnie jak w przypadku relikwiarza na głowę św. Stanisława fundacji królowej Zofii, którego nie przetopiono mimo przeniesienia czaszki do znacznie okazalszej złotej puszki fundacji Elżbiety Rakuszanki z r. $1504^{106}$.

Po zniszczeniu relikwiarza fundacji Zygmunta III w r. 1657, szczątki św. Stanisława ponownie włożono do średniowiecznej trumny i wystawiono na ołtarzu pośrodku katedry ${ }^{107}$. Już w czasie wizytacji przeprowadzonej w r. 1638 była ona znacznie uszkodzona, skoro odnotowano, że: habet multos in argento defectus in aliquot enim partibus personae decemnouem fusilis argenti desunt $\&$ particulae multo aliquot columellarum ${ }^{108}$. W $1670 \mathrm{r}$. zauważono $\mathrm{z}$ kolei brak głów kilku postaci.

Ostatecznie Kapituła postanowiła starą trumnę przetopić, co uczyniono przy okazji realizacji nowej z fundacji bp. Piotra Gembickiego (ukończonej w r. 1671). Uzyskano z niej 290 grzywien srebra (ok. 67,86 kg) ${ }^{109}$. Część kruszcu - 50 grzywien (ok. 11,7 kg) przeznaczono na krzyż i parę świeczników do ołtarza św. Stanisława ${ }^{110}$. Pozyskane srebro było próby trzynastej, lecz do wykonania garnituru ołtarzowego użyto stopu próby jedenastej, co dało ostatecznie wage 69 grzywien (ok. 16,14 kg) ${ }^{111}$. Kolejne 10 grzywien (ok. 2,34 kg) posłużyło do sporządzenia figury św. Kazimierza ${ }^{112}$. Pozostałe 230 grzywien (ok.

${ }^{105}$ AKM, Wiz. Zadzika 1638 (AVCap 34), k. 90r.; Lib. fabr. 2, k. 119r. (1634): Stolarzowi $z$ slioszarzem za drzwiczki do stary trumny S. Staniszlawa gdzie ręka. 3 [fl.], Za ramę do Baldachimu nad the trumne I [fl.], Za gradusze do wstepowania do reliquij 1. [fl.]; k. 121r. (1635): Za krate drotowa do grobu S. Staniszlawa. starego 8 [fl.]; Lętowski 1859, s. 7; Wojciechowski 1900, s. 90 .

${ }^{106}$ Dopiero od pocz. w. XVIII starszy relikwiarz zaadaptowano na stałe pomieszczenie czaszki św. Floriana, wcześniej głowa św. Stanisława zamknięta w osobnej srebrnej puszce mogła być przenoszona $\mathrm{z}$ jednego relikwiarza do drugiego (czy i w jakich okolicznościach praktykowano takie przenosiny, tego źródła nie podaja). Do dawnego też relikwiarza ofiarowała złotą koronę królowa Anna Jagiellonka.

${ }^{107}$ AKK, Lib. fabr. 2, k. 181v.: Ztotnikowi od wychendozenia Trumny S. Stanistawa 45; Rożek 1979, s. 449; R o że k 1980, s. 80.

${ }^{108}$ AKM, Wiz. Zadzika 1638 (AVCap 43), k. 90v.

109 AKK, Legati Gembiciani, s. 11; różnica w wadze podanej w r. 1631 (352 grzywny) i r. 1670 (290 grzywien) wynika zapewne z zastosowania różnych grzywien - wcześniej krakowskiej (ok. $0,196 \mathrm{~kg}$ ), później kolońskiej (ok. $0,234 \mathrm{~kg}$ ). Dokonując przeliczenia otrzymujemy odpowiednio: $68,99 \mathrm{~kg}$ oraz $67,86 \mathrm{~kg}$, a więc wartości bardzo zbliżone. Różnica $(1,13 \mathrm{~kg})$ może wynikać z niedokładności ważenia albo z ubytku srebra między 1631 a 1670.

${ }^{110}$ AKK, Legati Gembiciani, s. 11.

${ }^{111}$ AKK, Legati Gembiciani, s. 12.

112 AKK, Legati Gembiciani, s. 11. 
$53,82 \mathrm{~kg}$ ) rozprzedano uzyskując 11343 floreny ${ }^{113}$. Sumę tę połączono z pieniędzmi pozostatymi z legatu bp. Piotra Gembickiego przeznaczonego na pokrycie dachu skarbca (3 $970 \mathrm{fl} .26 \mathrm{gr}$ ) oraz przekazanymi przez krakowskich Żydów tytułem rekompensaty za zniszczony przez Szwedów srebrny ołtarz św. Stanisława (200 fl.) i z tego funduszu (15 $513 \mathrm{fl}$.) zapłacono za szereg prac przy wykończeniu nowej barokowej trumny.

W spisie inwentarzowym skarbca katedry krakowskiej z r. 1563 znalazł się osobny rozdział zatytułowany: Tabulae seu imagines, quae olim ad aram s. Stanislai pendebant loco imaginum prius quam imago argentea fuisset posita ${ }^{114}$. Opisano w nim jedenaście (później dopisano dwunasty) obrazów, w większości ozdobionych blachami srebrnymi i klejnotami. Musiały one odgrywać w średniowieczu istotną rolę w wystroju grobu św. Stanisława, zasługują więc na osobne, szczegółowe omówienie. Zacznijmy od ich opisu, wykorzystując informacje zawarte $w$ inwentarzach skarbca $i$ aktach wizytacyjnych katedry.

\section{Tryptyk: Trójca Święta oraz Maria z Dzieciątkiem i św. Jan Ewangelista ${ }^{115}$}

Tablica drewniana, w całości pokryta blachą srebrną złoconą ${ }^{116}$, kameryzowana kamieniami szlachetnymi (diamenty, rubiny, balasy, spinel, szafiry, szmaragd) i półszlachetnymi (almandyny, turkus) oraz perłami ${ }^{117}$. Przedstawienia wykonano techniką rytowania ${ }^{118}$. Obraz podzielony został na trzy kwatery,

${ }^{113}$ AKK, Legati Gembiciani, s. 11.

${ }^{114}$ Inwentarz katedry wawelskiej z roku 1563, opr. A. Bochnak, [Źródła do dziejów Wawelu X], Kraków 1979, s. 31-35; podobnie w AKK, Wiz. Maciejowskiego (nr 20), s. 33: Tabulae, seu imagines, quae olim pe[n]debant ad aram Sancti Stanislai loco imagin[um] priusqu[quam] haec imago argentea quae nunc est comparata esset. Item habet haec Ecclesia tabulas seu imagines portatiles quae olim pendebant ad aram S. Stanislai nunc autem asseruantur in Sacristia et pro solemnitatibus solent poni in altari maiori.

${ }^{115}$ Inwentarz 1563, s. 31-33 (tabula prima); Inwentarz 1586 (1-77), s. 21-22; Wiz. Maciejowskiego 1602 (nr 18), s. 39; Wiz. Maciejowskiego 1602 (nr 20), s. 33; Inwentarz 1620 (I-81), s. 17; Wiz. Trzebickiego 1670 (nr 51), s. 55.

${ }^{116}$ Inwentarz 1563, s. 31 : ex laminis argenteis ligno superinductis; w r. 1670 i 1711 błędnie rozpoznano blachę jako złotą (była ona zapewne grubo zlocona): AKK, Wiz. Trzebickiego (nr 51), s. 55, Wiz. Łubieńskiego (nr 63), s. 35.

${ }^{117}$ Inwentarz 1563, s. 31: multis lapidibus pretiosis et margaritis ornata; łacznie było 61 kamieni (z nich cztery już wypadły) i 68 pereł.

118 Inwentarz 1563, s. 31 podaje, że na tablicy jest exculpta imago; AKK, Wiz. Lubieńskiego (nr 63), s. 36: na blasze (...) rysowane; I. P o 1 k o w s k i, Skarbiec katedralny na Wawelu w 32 
na pewno nierównej szerokości (środkowa szersza, boczne węższe). W centrum wyobrażono Trójcę Świętą w redakcji określanej mianem Tronu Łaski. W prawej kwaterze widniała postać Matki Boskiej z Dzieciątkiem na ręku, w lewej św. Jana Ewangelisty trzymającego kielich. Obramienia kwater zdobiły monilia (w środkowej kwaterze osadzone w nich były kamienie $z$ perłami), między którymi rozmieszczono pojedyncze perły. Przedstawienie Tronu Laski wyróżniono szczególnie bogatą kameryzacją. Nimb wokół głowy Boga Ojca zdobiło 13 pereł oraz 3 szafiry (jeden $\mathrm{z}$ nich był mniejszy, sed pulchrior aliis) ${ }^{119}$. Na nimbie Chrystusa widniały 4 diamenty na przemian $\mathrm{z} 3$ perłami, zaś nad głową Gołębicy Ducha Świętego wprawiono mały trójkątny diament. Gwoździe w rękach i nogach Jezusa wieńczyły diamenty. Ponad dłońmi były napisy: nad lewą Iesus (z miejscem po brakującym kamieniu), nad prawą dwie litery, zapewne $X C$ (z rubinem). Na zakończeniach poziomego ramienia krzyża widniały monilia z kamieniami i perłami. Poniżej stóp Chrystusa znajdowało się podobne monilium między dwoma perłami. Tron, na którym zasiadał Bóg Ojciec (in columna throni), dekorowało 9 pereł. Ponadto na całej tablicy (może w tle?) rozsiane były 22 rubiny, almandyny i balasy oraz 2 szafiry, trójkątny diament i turkus. Dużo skromniej kameryzowane były kwatery boczne: płaszcze Marii i św. Jana spinały diamenty, a głowy postaci otaczały nimby lamowane 8 perłami. Ponadto, głowę Matki Boskiej wieńczyła korona z 2 diamentami. Wreszcie, pojedynczy diament wprawiony był powyżej napisu lesus przy głowie Dzieciątka (?).

Pierwotnie, opisany trójdzielny obraz zamykany był dwoma ruchomymi skrzydłami, zapewne drewnianymi, zdobionymi złotem malarskim (Clauditur haec tabula duabus aliis tabulis inauratis pictorali auro ${ }^{120}$.

Według inwentarza z 1563 tryptyk znajdował się na ołtarzu przy grobie św. Stanisława, zanim ustawiono tam srebrne retabulum $z$ fundacji Zygmunta I Starego, czyli do $1512^{121}$. Później przechowywano go w skarbcu katedry i wystawiano na ołtarzu głównym z okazji świąt. W 1586 Kapituła rozważała w jakim insignum locum go umieścić, tak, by był widoczny dla odwiedzających katedrę ${ }^{122}$.

tablicach autografowanych przedstawiony, Kraków 1882, s. 13, przyp. oraz Fabrica Ecclesiae Cracoviensis. Materiały źródtowe do dziejów katedry krakowskiej w XVIII wieku z archiwaliów kapitulnych $i$ kurialnych krakowskich, wybral i opr. B. Przybyszewski, [Źródła do dziejów Wawelu XIV, cz. 1, red. A. Franaszek], Kraków 1993, s. 139, nr 289: na blasze srebrnej sztychowany.

${ }^{119}$ Inwentarz 1563, s. 31.

${ }^{120}$ Inwentarz 1563 , s. 33.

${ }^{121}$ Inwentarz 1563, s. 31: Tabula (...), quae olim in altari ad tumbam s. Stanislai ponebatur, antequam imago argentea per serenissimum regem Sigismundum Primum esset comparata, stare solebat.

${ }^{122}$ AKK, Inwentarz 1586 (I-77), s. 21-22. 
W opisie z r. 1620 odnotowano istotne zmiany w jego wyglądzie. Otóż, w miejsce wspomnianych wyżej skrzydeł zamontowano dwa samodzielne dotąd obrazy. Były to: Chrystus Ukrzyżowany $z$ Maria $i$ św. Janem Ewangelista (poz. 3) oraz Matka Boska z Dzieciatkiem (poz. 7) ${ }^{123}$. W w. XVIII ten „kombinowany" tryptyk stracił walory użytkowe i znalazł się wśród sreber w skrzyni kapitulnej stanowiących swoistą rezerwę kapitałową (Cista Massae Capitularis). Składajace się na niego obrazy zostały na polecenie Kapituły przetopione $\mathrm{w} 1763 \mathrm{r}^{124} \mathrm{~W}$ sporządzonej $9 \mathrm{XI}$ tego roku specyfikacji uzyskanego $\mathrm{w}$ ten sposób srebra (próby trzynastej) podano łączną wagę obrazu Trójcy Świętej i ramy z malowanego obrazu Ukrzyżowania (poz. 2): 21 grzywien 2 huty (ok. $4,9 \mathrm{~kg})^{125}$.

Ze względu na pierwotny związek $\mathrm{z}$ grobem św. Stanisława oraz bogatą dekoracje tryptyk był kilkakrotnie opisywany w literaturze naukowej ${ }^{126}$. Podnoszono też kwestię identyfikacji jego fundatora. Według akt wizytacji kard. Bernarda Maciejowskiego z r. 1602 tabula miała powstać za sprawą Zygmunta I ${ }^{127}$. Informację tę podano tylko raz, brak jej zarówno we wcześniejszych, jak i późniejszych źródłach, kilku badaczy wprowadziło ja jednak do obiegu naukowego ${ }^{128}$ Taka teza jednak nie da się utrzymać. Autor inwentarza z r. 1602 zapewne pomyłkowo wpisał króla jako fundatora, mechanicznie powtarzając określenie $\mathrm{z}$ nagłówka, które dotyczyło jedynie nowej nastawy, która zastapiła ów obraz.

Przekazy źródłowe nie zawierają żadnych przesłanek, które by mogły doprowadzić do ustalenia osoby fundatora oraz czasu powstania tryptyku. Jedynym tropem może być informacja o użyciu w kameryzacji diamentów „ostrych" (acuti), co zdaje się oznaczać szlif piramidalny, a to wskazuje na schyłek średniowiecza (w. XV i pocz. w. XVI). Niestety, na tej podstawie nie da się oprzeć precyzyjnego datowania.

$Z$ dużą dozą prawdopodobieństwa można ustalić wymiary tryptyku. Jego wysokość podają zapisy inwentarzowe - półczwarta łokcia, czyli ok.

${ }^{123}$ AKK, Inwentarz 1620 (I-81), s. 17.

${ }^{124}$ Polk owski 1882, s. 13, przyp.; Fabrica.., s. 138, nr 289 (Specyfikacja argenterii ecclesiae cathedrali Cracoviensis ad conflandum de consensu cellmi principis Illrmi et rvmi domini Caietani Soltyk episcopi Cracoviensis, ducis Severiae ze skarbu die 23 octobris anno Domini 1763); A. B o c h n a k, Mecenat Zygmunta Starego w zakresie rzemiosta artystycznego, [w:] Studia do Dziejów Wawelu II, 1960, s. 135, błędnie przyjął, że tryptyk został zrabowany przez Szwedów w czasie „Potopu”.

${ }^{125}$ Fabrica.., s. 139 , nr 289.

${ }^{126}$ Lę towski 1859 , s. 88, 92, 94; P o lkowski 1882 , s. 6; Polkowski 1888, s. 28 -29 ; B o c hn ak 1960, s. 135-136; B ork ow sk a 1999, s. 230-231.

${ }_{127}$ AKK, Wiz. Maciejowskiego 1602 (nr 20), s. 33.

${ }^{128}$ Łętowski 1859 , s. 88 ; Polk owski 1882 , s. 6; B o chnak 1960, s. 135-136; Rożek 1979, s. 442. 
$51,2 \mathrm{~cm}^{129}$. Do ustalenia szerokości można dojść drogą pośrednią. Mianowicie, wiemy, że w początku w. XVII dołączono do tryptyku zamiast (?) dawnych skrzydeł dwa inne obrazy srebrne. Jednym z nich był wizerunek Matki Boskiej z Dzieciątkiem oraz herbami Polski i Węgier (poz. 7). Otóż, wyprzedzając tok wywodu, trzeba powiedzieć, że był on bliźniaczo podobny do obrazów fundacji Ludwika Węgierskiego - trzech zachowanych w skarbcu katedry w Akwizgranie $^{130}$ oraz jednego $w$ kościele pielgrzymkowym w Mariazell ${ }^{131}$. Podobieństwa między nimi były tak daleko idące, że z pełnym przekonaniem należy przyjąć, iż dotyczyły one także wymiarów. Zwraca uwagę, że akwizgrańska Koronacja Marii oraz Matka Boska z Dzieciqtkiem mają po $52 \mathrm{~cm}$ wysokości ${ }^{132}$, a więc prawie dokładnie tyle, ile wawelska tabula z przedstawieniem Trójcy Świętej $(51,2 \mathrm{~cm})^{133}$. Nic dziwnego, bo do roli nowych skrzydeł wybrano na pewno obrazy odpowiadające jej wysokością. Musiały one po zamknięciu zasłaniać całkowicie obraz środkowy. Tak więc, ich zsumowana szerokość była identyczna (lub prawie identyczna) z szerokością środkowej tablicy. Chociaź w archiwaliach nie podano tego akurat rozmiaru, to można go hipotetycznie określić. Zakładając bowiem, że krakowska Matka Boska miała proporcje zbliżone do proporcji wspomnianych obrazów z Akwizgranu, można przyjać, że wynosił on ok. $42 \mathrm{~cm}$. Mnożąc go przez dwa otrzymujemy $84 \mathrm{~cm}$. Taką właśnie szerokość mógł mieć wawelski obraz. W takim przypadku całkowita szerokość tryptyku $\mathrm{z}$ rozłożonymi skrzydłami liczyłaby w przybliżeniu $168 \mathrm{~cm}$.

2. Obraz relikwiarzowy: Chrystus Ukrzyżowany z Mariq i św. Janem Ewangelista ${ }^{134}$

Malowany na desce ${ }^{135}$ albo na płótnie ${ }^{136}$, ujęty w srebrną ramę i ozdobiony srebrnymi aplikacjami. Kameryzowany kamieniami szlachetnymi i półszlachetnymi (m.in. szafir, kryształ). W kształcie stojącego prostokąta (podlugo-

${ }^{129}$ AKK, Wiz. Trzebickiego 1670 (nr 51), s. 55: magnitudinis palmorum trium et medii; Wiz. Lubieńskiego (nr 63), s. 35-36: na pótczwarty ćwierci tokcia wysoki.

${ }^{130} \mathrm{Grimme} 1973$, s. $103-104$, poz. 82-84.

${ }^{131}$ E. Ś n i è y ń s ka-S to lot, Andegaweńskie dary złotnicze z herbami polskimi w Kaplicy Wegierskiej w Akwizgranie, FHA XI, 1975, s. 22-28.

${ }^{132} \mathrm{G}$ ri m m e 1973 , s. 103, poz. 82-83.

${ }^{133}$ Różnica 0,8 cm może wynikać z niedokładności pomiaru.

${ }^{134}$ Inwentarz 1563, s. 33 (tabula secunda); AKK, Inwentarz 1586 (I-77), s. 22; Wiz. Maciejowskiego 1602 ( $\mathrm{nr} 20$ ), s. 33; Inwentarz 1620 (I-81), s. 18; Wiz. Trzebickiego 1670 (nr 51), s. 56; Wiz. Łubieńskiego (nr 63), s. 38; Inwentarz 1761 (I-79), s. 47.

${ }^{135}$ Wiz. Trzebickiego 1670 (nr 51), s. 56; Wiz. Lubieńskiego (nr 63), s. 38.

${ }^{136}$ AKK, Inwentarz 1761 (I-79), s. 47; Polk ow sk i 1882, s. 12; Fabrica, s. 138, nr 289. Istnieje pewne prawdopodobieństwo, że był on malowany na płótnie naklejonym na deskę; nie można też wykluczyć pomyłki w rozpoznaniu rodzaju podobrazia. 
waty $)^{137}$. Zawierał relikwie umieszczone w jedenastu lub dwunastu reservaculach w formie rozet (in [...] locis seu rosis) ${ }^{138}$. Ozdobiony metalowymi motywami roślinnymi (argenti rami ${ }^{139}$ lub inaczej argentei flores maiores 24 minores 4 loco eis vacua tria) ${ }^{140}$. Nimby postaci wzbogacone były kameryzacją: szafiry wokół głowy Jezusa (trzy) i Marii (cztery), pięć nieokreślonych bliżej kamieni u św. Jana. Nie sprecyzowano miejsca, gdzie znajdował się duży kryształ, a także herb Starykoń (na ramie?, u podstawy krzyża?).

Po roku 1512 przechowywany w skarbcu katedralnym, w r. 1586 dyskutowano o nowym jego zastosowaniu i umieszczeniu w insignum locum, aby był widoczny dla odwiedzających kościót ${ }^{\mathrm{j} 1}$. Już w r. 1563 odnotowano znaczne braki w kamieniach i dekoracji roślinnej. W 1763 obraz na polecenie Kapituły przetopiono $^{142}$.

Przesłanką do określenia fundatora jest obecny na nim herb Starykoń. Bardzo więc prawdopodobne, że powstał on sumptem któregoś z Szafrańców, najważniejszej w średniowieczu rodziny pieczętującej się tym herbem. Mógł nim być na przykład twórca potęgi rodu, Piotr Szafraniec, podstoli krakowski (zm. 1398). Wchodzą w rachubę także dwaj politycy, którzy w zasadniczy sposób wpływali na rządy Władysława Jagiełły w latach 1428-1433: Piotr, wojewoda krakowski (zm. 1437) oraz Jan, kanclerz Królestwa (zm. 1433). Przypisanie im fundacji obrazu jest szczególnie prawdopodobne ze względu na związki, jakie łączyły ich $\mathrm{z}$ katedra. Przypomnieć trzeba, że oni to erygowali nową kaplicę pod wieżą Wikaryjską ${ }^{143}$.

\section{Obraz: Chrystus Ukrzyżowany z Mariq i św. Janem Ewangelista ${ }^{144}$}

Srebrny, częściowo złocony, na podkładzie drewnianym ${ }^{145}$. Zapewne w kształcie stojącego prostokąta. Na złoconej blasze tła krzyż z częściowo zło-

${ }^{137}$ AKK, Inwentarz 1761 (1-79), s. 47.

138 AKK, Wiz. Maciejowskiego 1602 (nr 20), s. 33. Część inwentarzy podaje liczbę 11 miejsc na relikwie, 12 zaś Wiz. Trzebickiego oraz specyfikacja z 1763: P olk ow sk i 1882, s. $12 ;$ Fabrica, s. 138, nr 289.

${ }^{139}$ Inwentarz 1563, s. 33.

${ }^{140}$ AKK, Wiz. Maciejowskiego 1602 (nr 20), s. 33; Inwentarz 1563, s. 33.

${ }^{141}$ AKK, Inwentarz 1586 (I-77), s. 22; Wiz. Maciejowskiego 1602 (nr 18), s. 39.

${ }^{142}$ P o 1 k ow sk i 1882, s. 12; Fabrica..., s. 139, nr 289.

${ }^{143}$ O rodzinie Szafrańców: J. Sperka, Szafrańcowie herbu Stary Koń. Z dziejów kariery i awansu w późnośredniowiecznej Polsce, Katowice 2001.

${ }^{144}$ Inwentarz 1563, s. 33 (tabula tertia); AKK, Inwentarz 1586, s. 22; Wiz. Maciejowskiego 1602 (nr 18), s. 39; Wiz. Maciejowskiego 1602 (nr 20), s. 33; Inwentarz 1620 (1-81), s. 17; Wiz. Trzebickiego 1670 (nr 51), s. 55; Wiz. Łubieńskiego (nr 63), s. 36. 
coną postacią Chrystusa oraz titulusem na górnej belce. Po bokach złocone figurki Marii i św. Jana. Osoby uczestniczące w scenie najprawdopodobniej wykonane techniką odlewania. Cała tablicę pokrywała niezwykle obfita kameryzacja (parvi pretii) ${ }^{146}$. Różnobarwnych kamieni było tak dużo, że w kolejnych inwentarzach nie zamieszczano ich szczegółowego wyliczenia. W 1670 było ich w sumie $174^{147}$, w 1711 natomiast 175 (brakowało 3 ) $^{148}$. W narożnikach rozmieszczono herby: u góry Polski i Litwy, u dołu Węgier. W 1711 odnotowano ramy drewniane złocone ${ }^{149}$.

Po r. 1512 obraz przechowywano w skarbcu katedralnym. W 1586 roku Kapituła postanowiła wystawiać go w święta na ołtarzu głównym ${ }^{150}$. Między 1602 a 1620 r. dołączono go jako skrzydło do tablicy z Trójcą Świętą (poz. 1) ${ }^{151}$. Uległ zniszczeniu w 1763 r., gdy przetopiono go na polecenie Kapituły ${ }^{152}$. Według zestawienia sporządzonego 9 XI 1763 r.: Figura P. Jezusa Ukrzyżowanego z Najświętszq Pannq i św. Janem na blasze srebrnej pozłocistej z kasztem od kamyków ważyły 10 grzywien (próby trzynastej), czyli ok. $2,34 \mathrm{~kg}^{153}$.

Wymiary tablicy były zapewne zbliżone do wymiarów obrazu Matki Boskiej z herbami polsko-węgierskimi (poz. 7). Użyto ich wtórnie jako skrzydła tryptyku z Trójcą Świętą (poz. 1), w tym celu musiano więc zastosować tablice podobnej albo wręcz identycznej wielkości. Trudno przecież przypuszczać, aby nowo utworzony tryptyk miał skrzydła asymetryczne.

Urszula Borkowska przypisała fundację obrazu Władysławowi Jagielle i św. Jadwidze ${ }^{154}$. Rzeczywiście, herby Królestwa Polski, Wielkiego Księstwa Litewskiego oraz Królestwa Węgier mogły się odnosić do tej pary monarszej. Ale czy nie mogła to być samodzielna fundacja królowej Jadwigi? Znamy z archiwaliów kilka innych przedmiotów sprawionych przez nią do katedry krakowskiej: srebrny krucyfiks, takież świeczniki i dzwonek, a także zachowany do dziś racjonal ${ }^{155}$. Dla wawelskiej świątyni był też prawdopodobnie przezna-

\footnotetext{
${ }^{145}$ Wiz. Maciejowskiego 1602 (nr 20), s. 33: laminis argenteis inauratis ligno superinductis.

${ }^{146}$ AKK, Wiz. Maciejowskiego 1602 (nr 20), s. 33.

${ }^{147}$ Wiz. Trzebickiego 1670 (nr 51), s. 55.

${ }^{148}$ AKK, Wiz. Lubieńskiego (nr 63), s. 36.

${ }^{149}$ AKK, Wiz. Lubieńskiego (nr 63), s. 36.

${ }^{150}$ AKK, Inwentarz 1586 (1-77), s. 22.

${ }^{151}$ AKK, Inwentarz 1620 (1-81), s. 17.

${ }^{152}$ Polk ow sk i 1882, s. 12, przyp.; Fabrica, s. 138, nr 289.

153 Fabrica..., s. 139 , nr 289.

${ }^{154}$ B ork ow ska 1999, s. $230-231$.

${ }^{155}$ Inwentarz 1563, s. 6, 28, 30, 56; Wawel 1000-2000. Wystawa Jubileuszowa, t. 1: Kultura artystyczna dworu królewskiego i katedry. Katedra krakowska - biskupia, królewska, narodowa, Kraków 2000, s. 214-215, poz. I/188 (oprac. M. Walczak), il. 252 (tam wcześniejsza literatura).
} 
czony kryształowy puchar, dziś w zbiorach drezdeńskich ${ }^{156}$. Charakterystyczne, że na żadnym $\mathrm{z}$ nich nie było Pogoni litewskiej, za to obok Orła Białego występował herb Bośni (krzyż, świeczniki) ${ }^{157}$ albo Andegawenów (racjonał, puchar). Ani na tych wymienionych dziełach, ani w Psalterzu floriańskim nie występuje herb Pogon ${ }^{158}$. W tej sytuacji bardziej prawdopodobna jest wspólna fundacja obojga królewskich małżonków: Jadwigi i Jagiełły. Być może, iż ta fundacja dała asumpt do zapiski o okryciu przez św. Jadwigę srebrnymi blachami trumny św. Stanisława ${ }^{159}$. Nie można jednak nie zauważyć jeszczej innej możliwości. Otóż, herbów Polski, Litwy i Węgier używał również król Władysław Warneńczyk $^{160}$. O fundacjach uczynionych przez niego na rzecz katedry krakowskiej źródła nic nie mówią, ale to sprawy nie przesądza. Pozostaje więc kwestię fundacji pozostawić nie rozstrzygnięta.

\section{Obraz: Chrystus Salwator ${ }^{161}$}

Niewatpliwie ikona ruska lub bizantyjska (opere Graeco), przedstawiająca Chrystusa Pantokratora nigra facie ${ }^{162}$. Malowany na drewnie. Ujęty w ramy pokryte blachą złotą z moniliami, ze złota wykonany również nimb wokół głowy Jezusa. Ozdobiony kamieniami niewielkiej wartości ${ }^{163}$.

W r. 1563 odnotowano znaczne uszkodzenia: brak trzech moniliów w narożnikach oraz licznych blaszek na ramach. W miejscach, gdzie na obrazie odpadły aplikacje dokonano uzupełnień złotem malarskim (auro pictorio) ${ }^{164}$. Część złotych ozdób oddano 17 VIII 1576 do skrzyni kapitulnej. Spośród zgromadzonych tam klejnotów wybrano takie, quae magis conspicua videbantur (...) ad reformandam crucem illam ligni vitae secundam ${ }^{165}$. Złotnikowi Foltynowi oddano $\mathrm{w}$ tym celu 29 moniliów, 4 rozetki, 4 knafliki, 9 różnych ka-

${ }^{156}$ Wawel 1000-2000, s. 46-48, poz. I/15 (oprac. J. Kappel, D. Nowacki), il. 15 (tam wcześniejsza literatura).

${ }^{157}$ Inwentarz 1563 , s. 6, 30; trzeba zaznaczyć, że nie mamy pełnej informacji na temat herbów na krzyżu, przy jego opisie podano: cum armis Regni Poloniae et Regni Hungariae [dopisano wyżej: Bosnae] ac aliis in sede quattuor [podkr. K.J.C.J. Herb Bośni odnosił się do matki Jadwigi, która była córką Stefana Kontromanica.

158 J a w ors k a 2003 , s. 88.

${ }^{159}$ MPH III, s. 68 , przyp. 1.

$160 \mathrm{~J}$ a worsk a 2003 , s. 89.

${ }^{161}$ Inwentarz 1563, s. 33 (tabula quarta); AKK, Inwentarz 1586 (I-77), s. 22; Wiz. Maciejowskiego 1602 (nr 20), s. 33; Inwentarz 1620 (I-81), s. 17.

162 Inwentarz 1563, s. 33.

${ }^{163}$ Inwentarz 1563, s. 33: octo lapides nullius pretii, alii exciderunt.

${ }^{164}$ Inwentarz 1563, s. 33, przyp. s-s.

${ }^{165}$ Inwentarz 1563 , s. 42. 
mieni, 2 perły i 1 koral. Dopełniono nimi braki w ozdobach krzyża wykonanego $\mathrm{z}$ diademów ${ }^{166}$. Być może były między nimi fragmenty z okładu obrazu Salwatora, jednak dzisiaj nie można się ich dopatrzyć wśród moniliów nałożonych na krzyż.

W r. 1586 rozpatrywano projekt przekazania obrazu do kościoła w Pabianicach lub którejś z wsi kapitulnych ${ }^{167}$. Po raz ostatni notowany prawdopodobnie w inwentarzu z $1620 \mathrm{r}^{168}$ Zastrzeżenie wynika stąd, że wówczas określono metalowe aplikacje jako srebrne złocone, a nie złote. Jednak identyfikacja $\mathrm{z}$ innym obrazem Salwatora (poz. 5) jest o tyle watpliwa, że w 1602 r. wymieniono wyłącznie jeden obraz o tej tematyce, właśnie $\mathrm{z}$ dekoracją ze złota, a więc obecnie opisywany.

Zły stan zachowania w r. 1563 może wskazywać na dawność tablicy, która była bez wątpienia dziełem średniowiecznym. Niestety, brak bliższych danych w opisach uniemożliwia wyjście poza to ogólne stwierdzenie. Nie ma również podstaw do wysunięcia propozycji co do osoby ofiarodawcy.

\section{Obraz: Chrystus Salwator ${ }^{169}$}

Zapewne ikona (picturae Graecae) Chrystusa Pantokratora cum aliqua imagine cuiusdem feminae seu regina ${ }^{170}$. Malowana na drewnie, $\mathrm{z}$ ramą oraz okładem tła ze srebra złoconego ${ }^{171}$. Nimb wokół głowy Jezusa ozdobiony siedmioma kamieniami ${ }^{172}$. Jak zapisano w r. 1563, cała tablica litteris Graecis seu Ruthenis respersa ${ }^{173}$. W r. 1586 rozpatrywano przekazanie tego obrazu do kościoła parafialnego w Dzierążni ${ }^{174}$. Być może zrealizowano ten zamiar, skoro w r. 1602 już go nie odnotowano w aktach wizytacyjnych.

Frapujące jest pytanie, kogo przedstawiała opisana w inwentarzu postać ,jakiejś kobiety czy królowej". Niestety, nie można dziś dać na nie odpowiedzi. Podobnie, nigdy się nie dowiemy, jaka była treść napisów na obrazie - czy

166 O krzyżu: Wawel 1000-2000, s. 180-183, poz. V/155 (oprac. R. Sachs, D. Nowacki), il. 203-204 (tam wcześniejsza literatura).

${ }^{167}$ AKK, Inwentarz 1586 (1-77), s. 22.

${ }^{168}$ Inwentarz 1620 (I-81), s. 17.

${ }^{169}$ Inwentarz 1563, s. 34 (tabula quinta); Inwentarz I586 (I-77), s. 22.

${ }^{170}$ Inwentarz 1563, s. 34.

${ }^{171}$ Inwentarz 1563, s. 34: laminis argenteis inauratis in marginibus et intus ornata praeter picturam.

${ }^{172}$ Inwentarz 1563, s. 34: restant quinque lapilli in diadematibus, duo exciderunt.

${ }^{173}$ Inwentarz 1563, s. 34, przyp. b.

${ }^{174}$ AKK, Inwentarz 1586 (I-77), s. 22. Dzierążnia - miejscowość w pow. pińczowskim należąca do dóbr stołowych biskupów krakowskich. 
miały one charakter czysto dewocyjny, czy też zawierały informacje na temat czasu i okoliczności jego powstania. Zródła wskazują, że rozmieszczone były na całej powierzchni, może tak, jak na ikonie Matki Boskiej w katedrze we Freisingu ${ }^{175}$. Nie wiadomo też, czy owe inskrypcje były w języku greckim czy ruskim (litteris Graecis seu Ruthenis), co przesądzałoby o pochodzeniu tablicy z Bizancjum lub z Rusi.

\section{Obraz: Matka Boska z Dzieciatkiem ${ }^{176}$}

Malowany na drewnie, $\mathrm{z}$ wyjątkiem postaci Marii pokryty okładem ze srebra złoconego, dekorowanym rozetami i gwiazdami ${ }^{177}$. Suknia Matki Boskiej zdobiona gwiazdami, nimb wokół jej głowy z pięcioma moniliami, w których 27 czerwonych i zielonych kamieni oraz perły. Na nimbie Dzieciątka trzy szmaragdy i cztery perły ${ }^{178}$.

Powyżej nimbów trzy monilia z 16 kamieniami i 14 perłami. Na rękawach sukni Marii (manelach) dwa monilia $\mathrm{z}$ czerwonymi i zielonymi kamieniami ${ }^{179}$. Ramy dekorowane pięcioma moniliami, w których 11 kamieni, wokół nich 28 pereł. Według inwentarza z 1563 r. cum armis Regni, Prussii crucum. Nieco inaczej brzmi ten zapis po późniejszej poprawce: cum armis Regni et Prussii duarum crucum $^{180}$. Po raz ostatni notowany w 1602 roku.

Kluczem do ustalenia fundatora i czasu powstania obrazu są oczywiście wspomniane wyżej herby. Niestety, zestawienie herbu Królestwa Polskiego i herbu Prus (w odmianie I?) nie naprowadza jednoznacznie na żadną konkretna osobę. W skarbcu katedry krakowskiej znajdował się szereg przedmiotów oznaczonych drugim z tych herbów. Znaczna ich część w 1563 określona została jako dary Tomasza Strzempińskiego, bp. krakowskiego w latach $1455-60^{181}$. Kolejne można $\mathrm{z}$ nim związać na podstawie innych źródeł i kontekstu historycznego ${ }^{182}$. Fundacje te opatrzone były Prusem I, w dwóch przypadkach wraz

${ }^{175}$ Diözesanmuseum Freising. Christliche Kunst aus Salzburg, Bayern und Tirol 12. bis 18. Jahrhundert, München-Zürich 1984, s. 244-251 (oprac. S. Benker).

${ }^{176}$ Inwentarz 1563, s. 34 (tabula sexta); AKK, Inwentarz 1586 (I-77), s. 23; Wiz. Maciejowskiego 1602 (nr 18), s. 40 .

${ }_{177}^{1 n w e n t a r z}$ 1563, s. 34: Tota tabula praeter imaginem laminis argenteis inauratis contecta.

${ }_{178}$ Inwentarz 1563, s. 34, w dopisku odnotowano w tym miejscu 3 rubiny.

${ }^{179}$ Inwentarz 1563, s. 34, sformułowanie: monilia gemmis rubeis et viridibus ornata absque perlis, może sugerować, że chodzi o barwne perełki (koraliki), a nie kamienie.

${ }^{180}$ Inwentarz $1563, \mathrm{~s} .34 \mathrm{z}$ przypisami.

${ }^{181}$ Inwentarz 1563, s. 15 (figurka św. Stanisława z 1460), 18 (złoty kielich), 21 (srebrny kielich), 55-56 (infuła).

${ }_{182}$ Inwentarz 1563, s. 36 (mszał), 38 (pontyfikał), 218 (pacyfikał z postacią św. Stanisława na stopie, przy ołtarzu św. Tomasza z Akwinu). Nie ma pewności co do identyfikacji fundatora w innych przypadkach: s. 24 (para ampułek), s. 220 (krzyż pacyfikalny w kaplicy śś. Kosmy i Damiana). 
z Leszczycem, nigdy zaś w połączeniu $\mathrm{z}$ herbem państwowym ${ }^{183}$. W tej sytuacji, na baczniejszą uwagę zasługuje srebrny kielich, który miał na stopie arma Regni, domus Austriae et Prussi i ${ }^{14}$. Herby Polski i Habsburgów każą w nim widzieć fundację królewską - Kazimierza Jagiellończyka lub Elżbiety Rakuszanki, lub ewentualnie któregoś z ich synów: Jana Olbrachta, Aleksandra lub Fryderyka. Ale do kogo odnosiłby się w tym kontekście herb Prus? Nasuwa się tutaj myśl o wspólfundatorze, którym mógł być np. wspomniany bp Tomasz Strzempiński, ale nie ma na to żadnych dowodów. Nie można też wykluczyć innego znaczenia wspomnianego herbu. Otóż, jak wiadomo, łączono go tradycyjnie ze św. Stanisławem. Co charakterystyczne, Prus I na złotym kielichu oraz figurce tego świętego, niewątpliwych darach Strzempińskiego, był odnoszony przez notariusza dokonującego opisu do św. Stanisława, a nie do fundatora (cum armis s. Stanislai, habens insignia s. Stanislai) ${ }^{185}$. Istnieje pewne prawdopodobieństwo, że w podobnym znaczeniu użyto herbów Prus I i Królestwa Polskiego na obrazie będącym przedmiotem naszej uwagi. W takim przypadku pierwszy odnosił się do Męczennika, drugi zaś do królewskiego fundatora.

Nie można pominąć jeszcze jednej wątpliwości, która budzi się przy lekturze opisu inwentarzowego z 1563 r. Dziwne bowiem wydaje się określenie godła herbu jako duarum crucum, czyżby więc „,dwa krzyże”, a może „podwójny krzyż"? W takim przypadku pod znakiem zapytania staje jego rozpoznanie jako Prus, który $w$ innych miejscach tego samego inwentarza opisany jest jako: semialtera lub sesqui crux, czyli „półtora krzyża”186. Gdyby rzeczywiście chodziło notariuszowi o „podwójny krzyż”, to można by go uznać za godło herbowe rodu Jagiellonów, co zupełnie zmieniałoby interpretację znaczenia obu herbów na obrazie. W tej sytuacji mógłby on być darem np. Władysława Jagiełły. Zbyt szczupła podstawa wnioskowania nie pozwala na sformułowanie jasnej hipotezy co do fundatora i datowania tablicy.

\section{Obraz: Matka Boska z Dzieciatkiem ${ }^{187}$}

Malowany na płótnie (wg akt wizytacji bp. K. Łubieńskiego w r. 1711) ${ }^{188}$, $\mathrm{z}$ wyjątkiem postaci pokryty srebrnym okładem. Maria w sukni pokrytej 38

${ }^{183}$ Inwentarz 1563, s. 36 (mszał), 38 (pontyfikał).

${ }^{184}$ Inwentarz 1563, s. 20.

185 Inwentarz 1563, s. 15, 18.

${ }^{186}$ Inwentarz 1563, s. 15, 18, 36, 38, 220.

${ }^{187}$ Inwentarz 1563, s. 34 (tabula septima); AKK, Inwentarz 1586 (I-77), s. 23; Wiz. Maciejowskiego 1602 (nr 18), s. 40; Wiz. Maciejowskiego 1602 (nr 18), s. 33-34; Inwentarz 1620 (I-8I), s. 17; Wiz. Trzebickiego (nr 51), s. 55; Wiz. Łubieńskiego 17I1 (nr 63), s. 36-37.

${ }_{88} \mathrm{AKK}$, Wiz. Lubieńskiego 1711 (nr 63), s. 36, pierwotnie zapewne malowany na drewnie, później mógł byćc wymieniony na nowy, na płótnie. 
gwiazdami ze srebra złoconego, wokoło złocone lilie na tle ciemnoniebieskiej emalii. ${ }^{189}$ Nimby Matki i Dzieciątka $z$ moniliami (odpowiednio siedmioma i trzema), w których osadzono czerwone i zielone kamienie oraz perły. ${ }^{190} \mathrm{Na}$ ramie 15 herbów Królestwa Polski i Wegier oraz 15 tabliczek zlocistych $w$ kwiaty dubrechowane ${ }^{191}$. W r. 1670 i 1711 wymieniono ponadto odlewane ze srebra, złocone przedstawienia Ewangelistów umieszczone w narożnikach ${ }^{192}$.

Między 1602 a 1620 r. połączony z obrazem Trójcy Świętej jako skrzydło tryptyku (zob. poz. 1).

E. Śnieżyńska-Stolot zauważyła podobieństwo obrazu wawelskiego do czterech zachowanych obrazów wiazzanych przez nią z Ludwikiem Węgierskim lub Elżbietą Lokietkówną (Akwizgran, Mariazell) i na tej podstawie zaliczyła go do tego samego zespoła ${ }^{193}$. Do tezy tej przychylili się kolejni badacze: E. Kovács ${ }^{194}$, E. Marosi ${ }^{195}$, U. Borkowska ${ }^{196}$, A. Jaworska ${ }^{197}$. Éva Kovács wyróżniła grupę wotywnych i grobowych koron ze srebra, fundacji węgierskich Andegawenów, zdobionych kamieniami w charakterystycznych oprawach z symetrycznie rozmieszczonymi perłami. Te właśnie oprawy łączą korony ze wspomnianymi wyżej czterema obrazami, w których zastosowano je w nimbach. Do tej samej grupy zaliczyła także zaginioną tablicę znaną z inwentarza skarbca katedry krakowskiej z $1563 \mathrm{r}$. oraz trzy pojedyncze klejnoty zamontowane na krzyżu $z$ diademów ${ }^{198}$. E. Marosi zwrócił uwagę w kontekście opisywanych obrazów na zjawisko powtarzalności, swego rodzaju „seryjności” w średniowiecznej produkcji złotniczej ${ }^{199}$. A. Jaworska włączyła wawelską

189 AKK, Wiz. Trzebickiego (nr 51), s. 55: caeruleo colore cum aureis liliis ornata; Wiz. Łubieńskiego 1711 (nr 63), s. 36.

${ }^{190}$ AKK, Wiz. Trzebickiego (nr 51), s. 55: lapillos vt vulgo dicitur pretiosos 36 . gemmulas 75: Wiz. Lubieńskiego 1711 (nr 63), s. 36, w samych moniliach na nimbie Marii wymienia 54 kamienie, 89 perełek i 3 koraliki, moniliów przy głowie Chrystusa już wtedy nie było.

${ }^{191}$ AKK, Wiz. Lubieńskiego 1711 (nr 63), s. 36-37.

${ }^{192}$ AKK, Wiz. Trzebickiego (nr 51), s. 55; Wiz. Lubieńskiego 1711 (nr 63), s. 36.

${ }_{193}$ Śnieżyńska-Stolot 1975 , s. 25; ta sama autorka omówiła wcześniej obrazy pokryte srebrnymi okładami, powstałe w kręgu Ludwika Węgierskiego i Elżbiety Rakuszanki, E. Śnieżyńska-Stolot, Geneza, styl i historia obrazu Matki Boskiej Częstochowskiej, FHA IX, 1973 s. 37-40.

${ }^{194}$ E. K o v a c s, Magyarországi Anjou koronák (Anjou Kronen von Ungarn), [w:] Ars Hungarica IV, 1976, s. 11, il. 4-6.

${ }^{195}$ E. M a ros i, Das Grosse Münzsiegel der Königin Maria von Ungarn. Zum Problem der Serialität Mittelalterlicher Kunstwerke, „Acta Historiae Artium Academiae Scientiarum Hungaricae" XXVIII (1982), s. 10.

${ }^{196}$ B ork owska 1999 , s. 231.

197 J a w o r sk a 2003, s. 86, autorka błędnie podaje datę inwentarza (1575) oraz, że obraz znajdował się przy grobie św. Wojciecha (!) w katedrze krakowskiej.

${ }^{198}$ K ovacs 1976, s. 11.

${ }^{199}$ Marosi 1982, s. 3-21. 
tablicę do rozważań na temat herbów używanych przez Elżbietę Łokietkównę 200 .

Do zbieżności między wizerunkami z Niemiec i Austrii a obrazem z katedry krakowskiej trzeba dodać także zbliżone rozmiary, o czym była mowa już wyżej. Dzieło wawelskie wyglądało zapewne podobnie jak jedna $\mathrm{z}$ podobizn Matki Boskiej w Akwizgranie oraz w Mariazell. We wszystkich przypadkach tło postaci pokryte jest blachami ze złoconymi liliami na błękitnej emalii. Także na ramach rozmieszczono po piętnaście plakiet $\mathrm{z}$ herbami na przemian $\mathrm{z}$ ażurowo wyciętymi motywami liściastymi. To one w inwentarzu katedralnym opisano jako „dubrechowane", co pochodzi zdaje się od niemieckiego „durchbrechen" - przełamywać, przebijać.

\section{Tryptyk: Matka Boska z Dzieciatkiem oraz śś. Piotr i Pawel ${ }^{201}$}

Malowany na drewnie (?). Wyróżniał się wielkością wśród innych obrazów, skoro określano go jako eminentis figurae ${ }^{202}$ bądź maioris figurae ${ }^{203}$. W środkowej kwaterze Matka Boska manibus Puerum complectantis (przedstawienie w typie Eleusy?). Nad jej głową biały szafir instar calcedoni. Na dwóch skrzydłach postacie śś. Piotra i Pawła. Zdobiony 17 koralami. W r. 1563 zaznaczono, że prawe skrzydło jest od zewnatrz obdarte ze srebra, później zaś dopisano, że w zamian dano blachę mosiężną ${ }^{204}$.

Po raz ostatni notowany w r. 1602.

\section{Obraz: Matka Boska z Dzieciatkiem ${ }^{205}$}

Malowany na drewnie (?), pokryty okładem srebrnym złoconym. Określany jako mały, ad instar Graece picturae (ikona?). Na głowie Marii korona zdobiona ośmioma rozetami, wokoło nimb złocony.

$200 \mathrm{~J}$ a w orska 2003 , s. 85-87.

${ }^{201}$ Inwentarz 1563, s. 35 (tabula octava); AKK, Inwentarz 1586 (I-77), s. 23; Wiz. Maciejowskiego 1602 (nr I8), s. 40; Wiz. Maciejowskiego 1602 (nr 20), s. 34.

${ }^{202}$ Inwentarz 1563 , s. 35.

${ }^{203}$ AKK, Wiz. Maciejowskiego 1602 (nr 20), s. 34.

${ }^{204}$ Inwentarz 1563, s. 35: alam dextram habens ab extra argento spoliatam [później przekroślono i dopisano: laceram, quae frustra locum occupant istae tabulae. Spoliatum et loco eius aerea lamina confecta].

${ }^{205}$ Inwentarz 1563, s. 35 (tabula nona); AKK, Inwentarz 1586 (I-77), s. 23; Wiz. Maciejowskiego 1602 (nr 18), s. 40; Wiz. Maciejowskiego 1602 (nr 20), s. 34. 
W r. 1563 zaznaczono, że obraz ten jest zazwyczaj noszony w procesjach na zewnątrz katedry. Notowany po raz ostatni w 1602. Helena Małkiewiczówna wiąze go hipotetycznie $\mathrm{z}$ obrazem przekazanym katedrze na mocy testamentu kard. Zbigniewa Oleśnickiego (datowanego $15 \mathrm{~V} 1454$ r.) ${ }^{206}$. Odpowiedni zapis brzmiak: Item Thalamum de Axamintho cum oponka texta in Axamento flaueo et ymagine beate virginis duplici tam texta in Atlassio Nigro cum literis Ruthenicis, quam picta in tabula opere greco ${ }^{207}$. Obraz miał więc stanowić komplet $\mathrm{z}$ haftowaną zasłoną (podea, pelena) ${ }^{208}$. Według Małkiewiczówny mógł on być elementem wyposażenia rezydencji Oleśnickiego $\mathrm{i}$ obiektem jego prywatnej dewocji ${ }^{209}$. Identyfikacja obrazu wspomnianego $\mathrm{w}$ testamencie $\mathrm{z}$ tablicą znaną z inwentarzy katedralnych budzi jednak wattpliwości, szczególnie ze względu na brak informacji o srebrnych zdobieniach tego pierwszego.

\section{Obraz: Matka Boska z Dzieciątkiem ${ }^{210}$}

Przedstawienie Marii z Dzieciątkiem (w typie Hodegetrii?). Malowany na drewnie, w całości, z wyjątkiem twarzy Marii, pokryty srebrnym złoconym okładem $^{211}$. Określany w źródłach jako „duży” (tabula magna). Suknia i korona Marii oraz ramy zdobione ornamentem "fercechowanym", czyli trybowanym.

Po raz ostatni opisany w $1711 \mathrm{r}^{212}$

\section{Dyptyk: Matka Boska z Dzieciatkiem oraz Veraicon ${ }^{213}$}

Malowany na drewnie (tempera), złocony. Na lewym skrzydle Matka Boska w półpostaci, z Dzieciątkiem na ręce. Na skrzydle prawym Veraicon. W tle obu części oraz $\mathrm{w}$ ramach komórki przykryte szkłem zawierające podpisane

${ }^{206}$ H. M a łk i e w i c zów n a, Zbigniewa Oleśnickiego "Imago Beatae Virginis duplex", [w:] Ars graeca Ars latina. Studia dedykowane Profesor Annie Różyckiej Bryzek, Kraków 2001, s. $122-124$.

${ }^{207}$ Ibidem, s. 122.

${ }^{208}$ Ibidem, s. 124-132.

${ }^{209}$ Ibidem, 135-136.

${ }^{210}$ Inwentarz 1563, s. 35 (tabula decima); AKK, Inwentarz 1586 (I-77), s. 23; Wiz. Maciejowskiego 1602 (nr 18), s. 40; Wiz. Maciejowskiego (nr 20), s. 34 (poz. 9); Inwentarz 1620 (I-81), s. 18; AKK, Wiz. Lubieńskiego (nr 63), s. 37.

${ }^{211}$ Inwentarz 1563, s. 35: tota argenteis laminis inauratis praeter faciem cooperta.

${ }^{212}$ AKK, Wiz. Lubieńskiego (nr 63), s. 37.

${ }^{213}$ Inwentarz 1563, s. 35 (tabula undecima); AKK, Inwentarz 1586 (I-77), s. 23; Wiz. Maciejowskiego (nr 18), s. 40 (poz. 10); Wiz. Maciejowskiego (nr 20), s. 34 (poz. 10); Inwentarz 1620 (1-81), s. 18; Wiz. Lubieńskiego (nr 63), s. 37-38; Lętowski 1859, s. 92. 
strannie relikwie świętych. Na głowie Marii korona ze złoconego srebra kameryzowana perłami i czerwonymi kamieniami, na jej płaszczu złocone gwiazdki. Ramy bogato zdobione różnobarwnymi kamykami ${ }^{214}$.

Na kwaterze z Marią wewnętrzny profil ramy ozdobiony srebrnymi złoconymi gwoździkami o główkach półkulistych, nacinanych gęsto na krzyż (naśladownictwo szyszki?), z kwadratowymi kryzami o faliście wykrojonych krawędziach.

Adam Bochnak po raz pierwszy dokonał identyfikacji obrazów zapisanych w inwentarzu z r. 1563 z zachowanym w skarbcu katedralnym dyptykiem relikwiarzowym ${ }^{215}$. Prześledzenie kolejnych spisów skarbca, w których je wymieniano (od r. 1563 do ok. 1880), potwierdza w pełni jej słuszność.

Ustalone przez J. Gadomskiego datowanie dyptyku na lata 1440-1450 nie budzi wątpliwości. Jego przyjęcie prowadzi jednak do wniosku, że fundatorem nie mógł być ten ks. Maciej Grodziecki, którego wskazał A. Bochnak. Kapłan ów żył bowiem w latach 1458-1517, a więc nie mógł zamówić obrazów w połowie w. $X V^{216}$. Wydaje się, że wzmiankowanego w inwentarzu z roku 1563 Mathiasa de Grodziecz należy identyfikować $\mathrm{z}$ jednym $\mathrm{z}$ wikarych wawelskich, który w r. 1472 ufundował ministerium w kaplicy śś. Macieja i Mateusza ${ }^{217}$.

Dzieło zostało wyczerpująco opracowane, co zwalnia autora niniejszego tekstu od powtórnego omawiania ${ }^{218}$.

\section{Dyptyk z przedstawieniem Veraiconu ${ }^{219}$}

Pojawił się po raz pierwszy w dopisku do inwentarza z r. 1563 jako Tabula duodecima Veronica parva claudens se alibus ${ }^{220}$. Odnotowany jeszcze w 1602, później znika z inwentarzy. Dopisanie do inwentarza w 1563 r. może swiadczyć o wtórnym dołączeniu go do zaspołu tablic zdobiących ołtarz św. Stanisława, ale nie można też wykluczyć, że został przeoczony podczas dokonywania spisu. Dotyczące go opisy są tak ogólne, że trudno cokolwiek więcej powiedzieć na jego temat.

${ }^{214}$ Wielu kamieni obecnie brak, na gómej ramie Veraiconu dodany później błękitny kamień w srebmym kaszcie z listkami na obrzeżu (zapewne w. XVII/XVIII).

${ }^{215}$ Inwentarz I563, s. 35, przyp. 18; rozpoznanie to przyjęli późniejsi badacze: S z c z e p k ow ska-N a liwajek 1996, s. 185; Wawel 1000-2000, s. 69-70, poz. I/33 (oprac. J. Gadomski), il. 42 (tam wcześniejsza literatura).

${ }^{216}$ Krótki biogram Macieja z Grodźca w: Inwentarz 1563, s. 282.

${ }^{217}$ L ę to ws k i 1859 , s. 13.

${ }^{218}$ Wykaz literatury w: Wawel 1000-2000, s. 69-70, poz. 1/33 (oprac. J. Gadomski), il. 42.

${ }^{219}$ AKK, Inwentarz 1586 (I-77), s. 23; Wiz. Maciejowskiego 1602 (nr 20), s. 40 (poz. 11); Łętowski 1859 , s. 88.

${ }^{220}$ Inwentarz 1563 , s. 35, przyp. i. 
Powyżej wymienione obrazy musiały powstać jeszcze w średniowieczu, skoro ustapiły miejsca ołtarzowi Zygmunta I w r. $1512^{221}$. Od tego czasu używano ich do dekoracji głównego ołtarza w czasie świąt. Na sesji Kapituły 11 maja 1534 r. zajęto się tą sprawą: Dum tabulas argenteas in celebrationibus festorum sanctuarii ad maius altare deferent, domini mandant, ut vicecustos ante et post missam summam easdem tabulas dilligenter revideat, ne aliquod in argento et margaritis aut lapidibus preciosis, quibus ornate sunt tabule, committatur $^{222}$. Jeszcze przed 1602 znika z zespolu wizerunek Salwatora w srebrnym okładzie (poz. 5), który prawdopodobnie zgodnie z sugestiami wysuniętymi w 1586 r. przekazano kościołowi parafialnemu w Dzierążni. Nieco później, w 1620 r., odnotowano brak kolejnych obrazów: dwóch z Matką Boską (poz. 6, 9), tryptyku z Marią oraz śś. Piotrem i Pawłem (poz. 8), a także dyptyku z Veraiconem (poz. 12). Nie wiadomo, co się z nimi stało, może także oddano je do kościołów w dobrach kapitulnych. W tym czasie opisano tryptyk z Trójca Świętą w nowej postaci, ze skrzydłami utworzonymi z obrazów Ukrzyżowania (poz. 3) i Marii (poz. 7). Przyczyn tej przeróbki trudno dociec. Zapewne uznano, że tak duża jak dotychczas liczba tablic jest całkowicie niepotrzebna, a dodanie dwóch szczególnie bogato zdobionych do największej nich uczyniło z niej dzieło wyjatkowo reprezentacyjne. Tak więc, liczbę dwunastu tablic zredukowano do pięciu. Po okupacji szwedzkiej, w 1670 r., zapisano jeszcze jeden, dotąd nie występujący w inwentarzach, obraz ze św. Janem Ewangelistą oraz herbami Królestwa Polskiego i Dębno, odnoszącym się może do kard. Zbigniewa Oleśnickiego ${ }^{223}$. Był malowany na desce, a zdobiły go srebrne ramy i okład pokryty 70 złoconymi gwiazdkami. Narożniki zaakcentowano dużymi kamieniami, po bokach rozmieszczono mniejsze. Wspomniane herby znajdowały się $\mathrm{w}$ jego górnej części (pod wierzchem) ${ }^{224}$. Trudno w tej chwili ustalić pochodzenie obrazu, niewykluczone, że dostał się do skarbca katedralnego z zewnątrz, w związku z zamieszaniem wywołanym przez wojnę ze Szwecją.

Ostateczny kres średniowiecznym „srebrnym tablicom" położyła decyzja Kapituły o przetopieniu ostatnich $\mathrm{z}$ nich w r. $1763^{225}$.

${ }^{221}$ Pewne wątpliwości budzi datowanie dyptyku z Veraiconem, zob. poz. 12.

${ }^{222}$ Wypisy źródłowe do dziejów Wawelu $z$ archiwaliów kapitulnych $i$ kurialnych krakowskich 1534-1535, wybór i oprac. B. Przybyszewski, [Źródła do dziejów Wawelu, t. X, cz. 3], Kraków 1987, s. 22, nr 1094.

${ }_{223}$ AKK, Wiz. Trzebickiego 1670 (nr 51), s. 55/56: S. Joannis Euangelistae totam deauratam habet laminam. Insignia Regia in ea duo conspiciuntur, Rosae octo integrae, nona defectuosa, lapis sapphiri instar, quantitatis sufficientis: lapilli minores minores 13 . in marginibus, stellulae 70. argenteae.

${ }^{224}$ AKK, Wiz. Lubieńskiego 1711 (nr 63), s. 37.

${ }^{225}$ P o l k o w s k i 1882, s. 12-13, przyp. 1; Fabrica, s. 138-139, poz. 289. 
Cechą wspólną wszystkich obrazów były ich niewielkie rozmiary, co umożliwiało ich przenoszenie ze skarbca (gdzie były na co dzień chowane) do ołtarza św. Stanisława i z powrotem. Kolejnym wyróżnikiem było użycie srebra do ich dekoracji. Należy tu rozróżnić obrazy w całości wykonane ze szlachetnego kruszcu, dalej malowane i pokryte prawie w całości okładem metalowym, oraz malowane i uzupetnione jedynie drobnymi aplikacjami srebrnymi. Tylko jeden z obrazów, Veraicon (poz. 12), nie miał żadnych ozdób złotniczych.

Dominują wśród wawelskich tablic wyobrażenia odnoszące się do boskiego dzieła Wcielenia (Matka Boska z Dzieciątkiem) oraz Odkupienia (Chrystus Salwator, Veraicon, Tron Laski). Zwraca uwage grupa ikon ruskich lub może nawet bizantyjskich ${ }^{226}$. Nie ma w tym nic nadzwyczajnego, wiadomo przecież, że wschodnie obrazy cieszyły się szczególną estymą na Zachodzie. Przykładowo można tu przypomnieć wspomnianą wyżej ikonę w katedrze we Freisingu (Konstantynopol, przed rokiem 1235) ${ }^{227}$, albo mozaikę św. Mikołaja w kościele opackim św. Jana w Burtscheid (Konstantynopol, w. XII, rama srebrna pocz. w. XIII) ${ }^{228}$. W Polsce doskonale zjawisko to ilustruje łaczona $\mathrm{z}$ bł. Salomea mozaikowa ikona Matki Boskiej w kościele św. Andrzeja ${ }^{229}$. Bardzo często obrazy wschodnie w całości pokrywano metalowymi okładami i zdobiono kosztownymi klejnotami. Wygląd takich dekoracji może przybliżyć np. ikona w skarbcu rezydencji w Monachium (w. XVI) ${ }^{230}$.

Na ile można sądzić na podstawie danych źródłowych, tablice zdobiące ołtarz św. Stanisława były dziełami kosztownymi i nietuzinkowymi pod względem poziomu artystycznego. Umieszczone na nich herby wskazuja na wysoko postawionych fundatorów i donatorów. Znajdujemy wśród nich królów i królowe (Ludwik Węgierski lub Elżbieta Łokietkówna, Władysław Jagiełło i św. królowa Jadwiga?) oraz przedstawicieli możnowładztwa (Szafrańcowie?). Wśród darów elity politycznej znalazł się też stosunkowo skromny dyptyk fundacji wikariusza katedralnego Macieja Grodzieckiego. Prawdopodobnie ma to związek z tym, że ołtarz św. Stanisława był obsługiwany przez wikarych. To oni odprawiali przy nim poranną Mszę św. zwaną missa matura. Niestety, część obrazów nie była oznaczona żadnymi herbami czy napisami, co uniemożliwia ustalenie ich pochodzenia. Nie da się więc odpowiedzieć na szereg ważnych pytań, np. czy były wśród nich fundacje biskupie.

${ }^{226} \mathrm{O}$ przedmiotach pochodzących z kręgu Kościoła Wschodniego w katedrze na Wawelu ostatnio H. M a łk i ew i c z ó w n a 2001, s. 121-143.

${ }^{227}$ Diözesanmuseum Freising 1984, s. 244-251 (oprac. S. Benker),

${ }^{228}$ E. G. G r i m m e, Kirchenschätze der ehemaligen Abteikirche St. Johann und der Pfarrkirche St. Michael in Aachen-Burtscheid, Aachen-Leipzig-Paris 1996, s. 21-32.

${ }^{229}$ Pax et Bonum 1999, s. 42-47, poz. III/1 (oprac. A. Róźycka-Bryzek), poz. IIU/1a (oprac. J. Żmudziński), il. I.

${ }^{230}$ The Treasury in the Residenz Munich. Official Guide, München 1988, s. 20, poz. 64. 
Srebrne obrazy, określane mianem tabulae, będące czasem jednocześnie relikwiarzami, znajdowały się również w kilku kaplicach katedralnych na Wawelu. I tak, w kaplicy Świętej Trójcy przechowywano dwa. Jeden miał formę złoconego tryptyku, który zawierał relikwie i wyobrażenia różnych świętych wykonane w technice emalii oraz scenę Zwiastowania Marii na zewnątrz skrzyde $^{231}$. Drugi określony jako tabula vetusta przedstawiał Matke Boską i ozdobiony był sześcioma kamieniami ${ }^{232}$. Szczególnie bogato wyposażona była kaplica Świętokrzyska. Jako prima et praecipua ac satis pretiosa opisana jest tabula obramiona dwudziestoma ośmioma kamieniami, pokryta dekoracją roślinną, z partykułami świętych zawartymi w dziewięciu krzyształowych moniliach, między którymi rozmieszczono dwanaście większych pere ${ }^{233}$. Dalej wymienić trzeba tryptyk z Chrystusem Ukrzyżowanym oraz Marią i św. Janem, wzbogacony relikwiami oraz opatrzony herbami Królestw Polski i Wegier ${ }^{234}$. Dwa srebrne dyptyki (pierwszy zdobiony emalia) stanowiły oprawę dla płaskorzeźb z kości wyobrażających Matkę Boską z Dzieciątkiem i Zdjęcie z krzyża. Znajdujace się na nich herby Polski i Austrii (Habsburgów) świadczyły o fundacji dokonanej przez królową Elżbietę Rakuszankę ${ }^{235}$. Najskromniejszy był obraz malowany na desce (picturae Graecae veteris), pokryty srebrnym okładem ${ }^{236}$. Nie do końca jasne jest, jaką techniką wykonano duae tabulae claudentes se in unam cum Christo in horto orante, in altera Comprehensio in horto - określenie ex laminibus subtilibus oznaczać może, że i one wzbogacone były złotniczymi elementami ${ }^{237}$. Kolejna królewska kaplica - Bożego Ciała (Jana Olbrachta) - posiadała srebrny, zdobiony emalią tryptyk zwieńczony grupą Ukrzyżowania (Chrystus, dwaj łotrzy, Maria i św. Jan Ew.) ${ }^{238}$. Ważył on 4 grzywny i 6 skojców (ok. $0,78 \mathrm{~kg})^{239}$. Szczególne zainteresowanie budzi srebrna złocona ta-

${ }^{231}$ Inwentarz 1563, s. 115.

${ }^{232}$ Inwentarz 1563, s. 116.

${ }^{233}$ Inwentarz 1563, s. 123.

${ }^{234}$ Herby odnosily się zapewne do królowej Elżbiety Rakuszanki; Inwentarz 1563, s. 125.

${ }^{235}$ Inwentarz 1563, s. 125.

${ }^{236}$ Inwentarz 1563, s. 125.

${ }^{237}$ Inwentarz 1563, s. 125, przyp. g; AKM, Wiz. Zadzika 1838, k. 49r.-v.

${ }^{238}$ Inwentarz 1563, s. 179; Lętowski 1859, s. 91, 94.

${ }^{239}$ Został on później opisany obszernie wśród przedmiotów w skarbcu katedry: Ottarzyk Srebrny wysoki na cwierc tokcia [ok. $14,65 \mathrm{~cm}]$ z iednej strony mysternie bardzo maiacy wyrobionq Szmelcem Annuntiationem Beatissimae, a pod Spodem odlewana Assumptionem Beatissimae cum personarum SSmae Trinitatis $Z$ drugiey Strony także Szmelcem wyrabiony Obraz S. Jerzego pod ktorym Spodem iest odlewana depositio de Cruce Christi Domini. Ten Ottarzyk tak a parte anteriori, iako tesz (!) y z tylu zowiera sie sktadanemi drzwiczkami rozmaite Icones na sobie misternie rysowane maiqcemi. Stoi ten Ottarzyk na czterech Aniokkach gatki pod sobq maiacych Wszytek ten Ottarzyk iest Srebrny sowicie ztocisty. Na Wierzchu tego Ottarzyka sa Effigies odlewane Beatissimae S. Joannis, et Mariae Magdalenae, byty znać y trzy krzyze ieden Christi 
blica w tej kaplicy: określona jako większa oraz portatilis, z relikwiami różnych świętych w przykrytych kryształami 18 kasztach, z kamieniem szarozielonym pośrodku. Inwentaryzator opatrzył ją uwaga: veteri more facta oraz przytoczył biegnący dokoła napis fundacyjny: Anno Domini 1341 frater Heinricus de Gera, provincialis terrae Kolmensis, hoc opus in honorem gloriosae Dei Genitricis et Virginis Mariae comparavit. Hoc opus ornatum, pia Virgo, sit tibi gratum ${ }^{240}$. $\mathrm{Z}$ akt wizytacyjnych z $1638 \mathrm{r}$. dowiadujemy się dalszych szczegółów: na srebrnych okuciach (bordiurach) były rytowane postacie dwunastu Apostołów, a w narożnikach Ewangeliści za szkłem ${ }^{241}$. L. Łętowski identyfikował słusznie opisaną tablicę jako portatyl $1^{242}$.

W kaplicy Zygmuntowskiej znajdował sie srebrny złocony tryptyk ofiarowany przez Annę Jagiellonkę 24 XII 1583 r. ${ }^{243}$ Przedstawiał płaskorzeźbiona scenę Koronacji Najświętszej Marii Panny. Zdobiło go 37 kamieni i 30 perel244. $Z$ tyłu widniała data: $1313^{245}$. Ważył 44 grzywny 8 uncji, a więc ponad $10 \mathrm{~kg}^{246}$. Wystawiano go na ołtarzu $\mathrm{z}$ okazji większych świąt ${ }^{247}$. Srebrny pacyfikał w kształcie tryptyku, przekazany przez królową wraz z wyżej opisanym obra-

Dni, a dwa latronum, teraz ne zostaie, tylko ieden dextri latronis, a Sinistri et Christi Domini deest; AKK, Wiz. Łubieńskiego (nr 63), s. 26-27.

${ }^{240}$ Inwentarz 1563, s. 180; Fundatorem tego relikwiarza był Heinrich de Gera, komtur chełmiński i elbląski. Dedykacja Marii może wskazywać jako miejsce jego przeznaczenia kościól, kaplicę lub ołtarz o wezwaniu maryjnym, ale równie dobrze może ona mieć charakter ogólny, oderwany od realiów fundacji. Obecność przedmiotu z 1341, krzyżackiego pochodzenia, w kaplicy ufundowanej dopiero w 1501 po śmierci Jana Olbrachta, sugeruje, że była to zdobycz wzięta w czasie jednej z wojen prowadzonych przez Polskę z Zakonem Krzyżackim. Nie można oczywiście wykluczyć możliwości zdobycia go w czasie Wielkiej Wojny w latach 1410-1411, po której Władysław Jagiełło ofiarował do kilku kościołów (m.in. do katedry krakowskiej) szereg trofeów, lecz bardziej prawdopodobne wydaje się wiązanie go z Wojną Trzynastoletnią. Relikwiarz, zabrany może z jednej z kaplic zamkowych, mógł się znaleźć w posiadaniu Kazimierza Jagiellończyka, a następnie stać własnością jego żony, Elżbiety Rakuszanki. Ona to zapewne złożyła go w ufundowanej przez siebie kaplicy Bożego Ciała. O polskich zdobyczach w zakresie złotnictwa w okresie wojen z Krzyżakami zob. K. S z c z e p k ow s k a - N a l i w a j e k, Złotnictwo gotyckie Pomorza Gdańskiego, Ziemi Chetminskiej i Warmii, Wrocław-Warszawa-Kraków-Gdańsk-Lódź 1987 , s. 33.

${ }^{241}$ AKM, Wiz. Zadzika 1638 (AVCap. 34), k. 106v.: Item habet pacificale argenteu(m) al(ia)s portatile viridis lapidis laminis argenteis consolidatu(m) in qua lamina habentur figurae duodecim Ap(osto)loru(m) exculptae in quatuor cornibus sub vitro quatuor Euangelistae et circumcirca reliquias habet notabilis et magni momenti SS.

${ }^{242}$ Łe tow ski 1859 , s. 91.

${ }^{243}$ Kaplica Zygmuntowska. Materiały źródłowe 1517-1977, wybór i oprac. A. Franaszek, B. Przybyszewski, [Źródła do dziejów Wawelu XIII, red. A. Franaszek], Kraków 1991, s. 53.

${ }^{244}$ Kaplica Zygmuntowska, s. 53, 60, 76, 94-95, 105.

${ }^{245}$ Kaplica Zygmuntowska, s. 94-95.

${ }^{246}$ Kaplica Zygmuntowska, s. 151.

${ }^{247}$ Kaplica Zygmuntowska, s. 76. 
zem, choć opatrzony herbem donatorki, był, jak wskazywał napis, fundacja z r. 1532 Pawła Holszańskiego, biskupa łuckiego ${ }^{248}$. Zawierał on liczne relikwie rozmieszczone wokół okrąłłego wizerunku Baranka Bożego, a w górnej części zdobił go kwadratowy balas i dwa szafiry ${ }^{249}$. Ważył 18 grzywien (ok. $\left.4,21 \mathrm{~kg}\right)^{250}$.

W wawelskiej kolegiacie św. Michała znajdował się zawierający relikwie obraz okryty srebrnymi blachami, wysadzany 33 kamieniami, ukazujący Marię opłakująca Chrystusa zdjętego z krzyża ${ }^{251}$.

Inwentarze notują też skromniejsze obrazy bez srebrnych okładów lub rozbudowanych ozdób. W kaplicy Różyców znajdowała się tabula antiqua imaginis Beatae Virginis Puerum gestantis ${ }^{252}$. W kaplicy Mansjonarskiej, w osobnej szkatule przechowywano obraz Beatae Virginis cum reliquiis sanctorum in circumferentia inclusis ${ }^{253}$. Kolejne obrazy odnajdujemy w kaplicach: śś. Macieja i Mateusza (tabella pacificalis pyramidalis) ${ }^{254}$, Kosmy i Damiana (tabula pacificalis cum reliquiis sanctorum) ${ }^{255}$, oraz przy ołtarzach: św. Doroty (tabella parva, picta, vetus, Misericordiae Domini) ${ }^{256}$, św. Wincentego (ligneae tabulae duae cum litteris Maria) ${ }^{257} \mathrm{i}$ św. Jana Ewangelisty ante Portam Latinam (tabella cum Veronica) ${ }^{258}$.

Tabulae z katedry krakowskiej nie stanowiły w Polsce odosobnionej grupy. Należą one do typu obrazów niewielkich rozmiarów (portatywnych) - pojedynczych lub łączonych w dyptyki i tryptyki. Zazwyczaj były one malowane na drewnie, czasem pokrywane srebrnymi lub złotymi blachami, rzadziej zaś wykonane w całości z metalu. Odmienną kategorię stanowią miniaturowe ołtarzyki, których wyróżnikiem są architektoniczne oprawy imitujące retabula ołtarzowe dużych rozmiarów ${ }^{259}$. Niektóre $\mathrm{z}$ tablic służyły wyłącznie do prezentacji relikwii, częściej jednak łączyły funkcje „klasycznego” obrazu i relikwiarza.

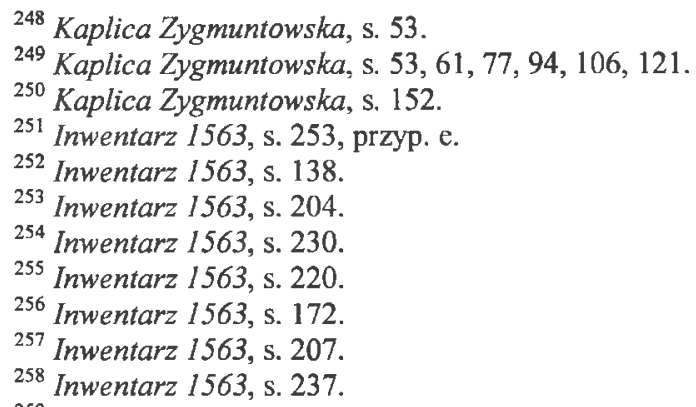

${ }^{259}$ W katedrze tę kategorię reprezentowały m.in. ołtarzyki w kaplicy Jana Olbrachta oraz w kaplicy Tomickiego. Charakter tego rodzaju dzieł doskonale ilustruje oltarzyk relikwiarzowy ufundowany w r. 1511 przez bp. Jana Turzona do katedry wrocławskiej (ob. w skarbcu klasztoru paulinów na Jasnej Górze), J. G o l o n k a, J. Ż m u d z i ń s k i, Skarbiec Jasnej Góry, Jasna Góra 2000 , s. 262-263, il. 28-29. 
Właśnie obrazom relikwiarzowym poświęcono szczególnie wiele uwagi w literaturze naukowej ${ }^{260}$.

Doskonałą ilustracją wyżej scharakteryzowanego typu może być obraz Matki Boskiej z Dzieciątkiem z bogatym złotniczym wystrojem i relikwiarzowymi ramami, zachowany w klasztorze kanoników regularnych laterańskich przy kościele Bożego Ciała w Krakowie ${ }^{261}$. Na co dzień przechowywano go w zakrystii, wynosząc do publicznej adoracji w święta ${ }^{262}$. Dość licznie zachowały się natomiast obrazy bez aplikacji. W samej katedrze znajduje się Matka Boska z Dzieciatkiem w ramie relikwiarzowej z lat ok. $1500-1520^{263}$. Ograniczając się do Małopolski można wymienić m.in. obrazy w klasztorze klarysek w Starym Sączu (ok. 1445), w Krakowie u dominikanów (przed 1450), kapucynów (ok. 1450-1460), w kościele Mariackim (ok. 1470), karmelitanek na Wesołej $(1499)^{264}$, dyptyk w Muzeum Diecezjalnym w Sandomierzu (1450$-1460)^{265}$. Trzeba tutaj wspomnieć także o obrazach bez relikwii, wyróżniających się niewielkimi rozmiarami, np. Misericordia Domini w kościele św. Anny w Krakowie (ok. 1480-1500) ${ }^{266}$.

Pełniejsze opracowanie tego rodzaju dzieł wymaga pełnego zebrania zachowanych zabytków, ale i szerokiej kwerendy źródłowej. Wstępne rozpoznanie dokonane przez autora, głównie w publikowanych archiwaliach, pozwala jedynie na przywołanie pojedynczych przykładów. I tak, cały szereg obrazów znajdujemy w piętnastowiecznych inwentarzach kościoła Mariackiego w Krakowie $^{267}$. Dwa z nich przedstawiały Matkę Boską (jeden zdobiony blaszka-

${ }^{260}$ Obrazy relikwiarzowe omawiają m.in.: S zc zepkowska-Naliwajek 1996, s. 183 -190; D. Pre i s in g, Bild und Reliquie. Gestalt und Funktion gotischer Reliquientafeln und alterchän, Aachener Kunstblätter 61, 1995-1997, s. 13-84.

${ }^{261}$ Wawel 1000-2000, s. 43-44, poz. IL/2 (oprac. H. Małkiewiczówna), il. 407 (tam wcześniejsza literatura). Watpliwości budzi wiąanie srebrnego okładu i ram z przemalowaniem obrazu w Krakowie; niezwykle wyrafinowana, doskonała pod względem warsztatowym dekoracja wykonana rzadko stosowaną techniką pointillé skłaniają raczej do wniosku, że obraz sprowadzono z Czech razem z metalową oprawą (o technice punktowania: K. Szczepkowska-Naliwajek, Technika „pointillé" w sztuce początku XV wieku, [w:] Artes atque humaniora. Studia Stanislao Mossakowski sexagenario dicata, Warszawa 1998, s. 25-30).

${ }^{262}$ K. L a t a k CRL, Kanonicy regularni laterańscy na Kazimierzu w Krakowie do końca XVI wieku, Ełk 1999, s. 125.

${ }^{263}$ Warwel 1000-2000, s. 82, poz. V/42 (oprac. J. Gadomski), il. 60 (tam wcześniejsza literatura).

${ }^{264}$ Obrazy w ramach relikwiarzowych zestawiła ostatnio H. Małkiewiczówna w: Wawel 10002000 , s. 44 , poz. II $/ 2$.

${ }^{265}$ Wawel $1000-2000$, s. 46-47, poz. II/5 (oprac. H. Malkiewiczówna), il. $409-411$ (tam wcześniejsza literatura).

${ }^{266}$ Wawel 1000-2000, s. 51-52, poz. II/9 (oprac. H. Małkiewiczówna), il. 408 (tam wcześniejsza literatura); oryginalne ramy nie zachowały się, a więc nie można wykhuczyć, że i ten obraz wzbogacony byl pierwotnie relikwiami.

${ }^{267}$ Ostatnio wzmiankuje o nich E. P i w o w a r c z y k, Dzieje kościola Mariackiego XIII$-X V I$ w.), Kraków 2000, s. 167, 172, 174, 226. 
mi $?^{268}$, drugi pokryty blachą srebrną złocona ${ }^{269}$ ). Kolejny ukazywał Wniebowzięcie NMP i zawierał relikwie w zaszklonych komórkach ${ }^{270}$. Był też obraz relikwiarzowy ${ }^{271}$ oraz takiż dyptyk, który oddano do ratusza ${ }^{272}$. Szczególną uwagę budzi jednak wzmianka o małej kwadratowej tablicy ze złota, bliżej nie scharakteryzowanej ${ }^{273}$. Następne obrazy opisano szerzej w inwentarzu z r. 1584:

Obraz Panny Maryi srebrem oprawiony na okoto, na którym sq herby królestwa wegierskiego i polskiego, na piersiach kamień wielki szafir, pertami osadzony. Jednak na tym obrazie wiele peret i różyczek niedostaje.

Obraz drugi Najśw. Panny także srebrem oprawiony: na okolo głowy sa koronki srebrne kamieniami osadzone, $i$ obraz jest kamieniami osadzony na wielu miejscach.

Dwie tablice stare $z$ wyobrażeniem Matki Boskiej, które maja na glowach korony $z$ pertami i kamieniami ${ }^{274}$.

W skarbcu katedry gnieźnieńskiej znajdowały się również interesujące nas przedmioty. W r. 1318 były to dwie tablice obwiedzione złotem i zdobione kamieniami szlachetnymi ${ }^{275}$. W 1450 r. zanotowano także dwa obrazy, ale pokryte srebrem złoconym. Oba zawierały relikwie ${ }^{276}$. Taką samą liczbę tablic relikwiarzowych posiadała kolegiata w Sandomierzu w 1552 r. Na jednej znajdował się wizerunek Marii (ze srebrnym krzyżem pektoralnym), na drugiej Misericordia Domini $^{277}$. Kończąc ten krótki przegląd, przypomnieć jeszcze trzeba o licznych

${ }^{268}$ Najstarsze inwentarze skarbca kościoła N.P. Maryi w Krakowie z XV wieku, wyd. F. Piekosiński, SKHS IV, 1891, s. 65: Prima ymago beate uirginis iammis [raczej raczej: lammis, przyp. K.J.C.] decorata.

${ }^{269}$ Najstarsze inwentarze 1891, s. 69: Item tabula maior beate Virginis argento deaurato superducta.

${ }^{270}$ Najstarsze inwentarze 1891, s. 69: Item tabula, in medio est Assumpcio beate Virginis, latera sunt vitree et subtus sunt reliquie (et in Superiori parte est parua tabula aurea sub vitro).

${ }^{271}$ Najstarsze inwentarze 1891, s. 76: Nota, quod ad ecclesiam beate virginis Marie, quod domina Trewthelyn pye memorie dedit vnum calicem et vnum missale et duos ornatos et vnum crinale cum iammis decorata et vnum tabulem [sic] cum diuersis reliquijs temporibus.

${ }^{272}$ Najstarsze inwentarze 1891, s. 69: Item vna tabula dupla, per totum lignea, intrinsecus deaurata et est vitrea, subtus sunt reliquie, et non est ecclesie, sed presentata erat dominis ad pretorium, eo, quia subtracta erat, sed nescitur cui, ideo eam impetenti quandoque reddi debet.

${ }^{273}$ Najstarsze inwentarze 1891, s. 67: Item parua tabula aurea de latitudine et longitudine trium digitorum, quadrata.

${ }^{274}$ A. G r a b o w s k i, Skarbniczka naszej archeologji, Lipsk 1854, s. 158.

${ }^{275}$ Inwentaria Ecclesiae Cathedralis Gnesnensis, wyd. W. Kętrzyński, MPH V, Lwów 1888 , s. 949: Item tabulam auream, s. 950: Item tabulam circumdatam lamis aureis et gemmis preciosis. Item aliam magnam tabulam auro circumdatam et gemmis preciosis.

${ }_{276}$ Ibidem, s. 951: Item tabula quadrangularis inaurata, plena reliquiis., s. 953: Item tabula argentea inaurata et gemmata, in qua est crux de ligno vite.

${ }^{277}$ [Inwentarz skarbca kolegiaty w Sandomierzu z 1552], SKHS IV, 1891, s. V: Item una tabula, imaginem b.V.M. ostentans habens argenteum pectorale, in quo est crux parva argentea et reliquiis circumposita est. 
portatywnych obrazach ze srebra pojawiającycych się w spisach wyposażenia kaplic w zamkach krzyżackich w Prusach ${ }^{278}$.

Nie ulega wątpliwości, że liczne tablice znajdujące się w krakowskim kościele katedralnym służyły do dekoracji ołtarzy w czasie Mszy św. ${ }^{279}$ Niektóre, szczególnie cenne, wystawiano tylko w święta i uroczystości (np. obraz z Koronacją Marii w kaplicy Zygmuntowskiej) ${ }^{280}$. Ale nie służyły tylko ozdobie, bowiem niekiedy pełniły funkcję pacyfikałów. W inwentarzach czasem znajdujemy wskazujący na to zapis: Pacificalis loco est tabella (ołtarz św. Doroty) ${ }^{281}$, tabella (...) loco pacificalis (ołtarz św. Jana Ewangelisty) ${ }^{282}$, Pacificale nullum, nisi (...) tabulae duae (ołtarz św. Wincentego) ${ }^{283}$, tabula pacificalis (kaplica śś. Kosmy i Damiana) ${ }^{284}$, tabella pacificalis (kaplica śś. Macieja i Mateusza) ${ }^{285}$. Warto w tym miejscu zauważyć, że taki użytek czyniono prawdopodobnie i z wielu zachowanych do dziś w polskich zbiorach obrazów relikwiarzowych, a takźe tych bez relikwii, lecz niewielkich rozmiarów. Niekiedy przedstawia się je w literaturze jako obiekty prywatnej dewocji, co oczywiście w pewnych przypadkach może być słuszne - kryteria takiego określenia funkcji są jednak bardzo niejasne ${ }^{286}$ - ale te, których przynależność do wyposażenia ottarza jest udokumentowana źródłowo, przeznaczone były niemal na pewno do celów liturgicznych $^{287}$. Trudniej określić natomiast charakter obrazów zachowanych w klasztorach, ponieważ mogły się one znajdować w celach, gdzie shużyły pobudzeniu indywidualnej pobożności zakonników i zakonnic. Funkcję litur-

Item alia tabula, imaginem Salvatoris alias Pietatis et b.V.M. in se continens, habens reliquias sanctorum circumpositas.

Item tres tabulae ligneae cum reliquiis sanctorum, in vitro reclusae.

${ }^{278} \mathrm{~S} \mathrm{zczepkowska-Na}$ l i wajek 1987, s. $12-13$.

${ }^{279}$ Ołtarz ze sprzętami, które na nim ustawiano w czasie mszy św. dokładnie przedstawia np. miniatura w tzw. Pontifikale Gundekarianum z 1496: Biskup Wilhelm z Reichenau odprawiajacy mszę św. (Archiwum Diecezjalne w Eichstätt), jest wśród nich oparty o predellę dyptyk z popiersiami Chrustusa Salwatora i Marii.

${ }^{280}$ Zob. przyp. 251-252.

${ }^{281}$ Inwentarz 1563, s. 172.

282 Inwentarz 1563, s. 237.

${ }^{283}$ Inwentarz 1563, s. 207.

${ }^{284}$ Inwentarz 1563, s. 220.

${ }^{285}$ Inwentarz 1563, S. 230. Do podobnej kategorii zaliczyć można miniaturowe ołtarzyki używane jako pacyfikały, zob. Ibidem, s. 142 (kaplica Szafrańców), s. 190 (ołtarzyk przysłany z Rzymu Piotrowi Tomickiemu przez bpa Erazma Ciołka), s. 245 (kaplica Hińczów).

${ }^{286}$ Por. nie prowadzące do jasnej konkluzji rozważania w: W. M a r c i n k o w s ki, Przedstawienia dewocyjne jako kategoria sztuki gotyckiej, Kraków 1994, passim, szczególnie s. 57-73, 81.

${ }^{287}$ Takie było niewątpliwie przeznaczenie np. obrazów z ok. 1470-80 z kaplicy Kuśnierzy w kościele Mariackim w Krakowie wiązanych z Janem Wielkim (ob. Muzeum Narodowe w Krakowie, dep. 8, 9); J. G a d o m s k i, Gotyckie malarstwo tablicowe Matopolski 1460-1500, Warszawa 1988 , s. 110, il. 87-98. 
giczną pełniły oczywiście bursy skrzynkowe dekorowane zazwyczaj malowidłami o tematyce pasyjnej (m.in. Veraicon), o których pisała Magdalena Piwocka przy okazji opracowania wieka takiej bursy zachowanego w kościele parafialnym w Sulisławicach ${ }^{288}$.

Nie ulega wątpliwości, że powyższy tekst może tylko częściowo wypełnić dotychczas istniejące luki w wiedzy na temat dziejów ołtarza św. Stanisława w katedrze krakowskiej. Wypada wyrazić jednak nadzieję, że przyczyni się on do przybliżenia wiążących się z tym zagadnień nie tylko wąskiemu gronu historyków i historyków sztuki, ale i szerszemu gronu zainteresowanych historią Kościoła oraz czcicielom św. Stanisława - w 750. rocznicę jego kanonizacji. Na omówienie w przyszłości oczekują m.in. tak interesujące elementy grobu Męczennika jak srebrny ołtarz z 1512 r. fundacji Zygmunta I oraz dary złotnicze członków królewskiej dynastii Wazów. Autor artykułu przygotowuje na ten temat osobną rozprawę.

\section{Silver Furnishings of Medieval Altar of St. Stanislaus in Cracow Cathedral Summary}

The article looks at these elements of St. Stanislaus' tomb in the Gothic Cathedral on the Wawel Hill which were made of silver. Except for one (a reliquary diptych) all were destroyed and are known only from written records.

The basic issue is to establish the date and the founder of a wooden coffin covered with gilded silver plates, in which the relics of the Martyr were placed. The literature on the subject attributed the foundation of the reliquary to St. Kunegunda (1234-1292), Elizabeth of Poland (1305-1380), St. Jadwiga, Hedvig of Anjou (1374-1399) and Ladislaus the Short (1260 or 1261-1333). Thanks to the records written in 1631 by a priest Jan Wielewicki which mention the renovation of the medieval coffin, we know that it had an inscription which unequivocally pointed to the person of Elizabeth of Poland, wife of a Hungarian king Charles I Robert and mother of a king of Hungary and Poland Louis d'Anjou, as the founder. A detailed description included in the records of an inspection of the Cracow Cathedral in 1670 allows an approximate reconstruction of this work of art, which was a box-reliquary of approximate measurements: $175,8 \times 87$, $9 \times 43,95 \mathrm{~cm}$, closed with a ridge roof cover of unknown height. It had cast decoration. The longer sides were each interspersed with 6 and the shorter with 2 pictures with the scenes from St. Stanislaus's life. Likenesses of 18 bishops adorned both patches of the

${ }^{288}$ M. P i w o c k a, „Misericordia Domini” z Sulistawic, FHA XXIX, 1993, s. 49-83. 
cover while on the triangular frontons the figures of eagles were given prominence. The corners and axes of the shorter sides were accentuated with buttresses. Top rims of the cover were decorated with an open-work comb (tracery). Iconographic programme cannot be reconstructed on the basis of the existing sources. After a new coffin for the remains of the Saint was funded by Sigismund III, the old one was used as a reliquary for the hand and placed in St. Peter and Paul's chapel, which - according to tradition originally housed the tomb. After the cathedral was looted by the Swedes in 1657, the medieval reliquary was put back in the middle of the church. Then, in the years 1669-1671 , when a new silver coffin was funded by bishop Piotr Gembicki, it was re-cast.

An important element of St. Stanislaus' altar decoration before 1512 (when Sigismund I had an imposing silver retable made) were paintings which were kept in the treasury and placed on the mensa during the liturgy. Inventories list 12 'plates' in all, some of which were made of silver, some covered with silver sheet metal (frames, dresses) and some only decorated with such appliqué. The most imposing was a triptych with the Holy Trinity engraved on sheet metal and richly set with jewels (in the type of Throne of Mercy) and the figures of Mary with the Child and St. John the Evangelist. Among the rest the most prominent were the depictions of the Salvator and the Virgin Mary with the Child. Some were accompanied by markings indicating their Byzantine or Ruthenian origins. A painting of Mary holding little Jesus in her arms, covered with a silver plate with lilies in the background, set with jewels and pearls, in a frame decorated with Polish and Hungarian coats of arms deserves special attention. It can undoubtedly be considered as a twin work to the three paintings stored in the treasury in Aachen and one in Mariazell, funded by Louis d'Anjou. The only painting of those which used to adorn the altar of St. Stanislaus which has survived to the present is the reliquary diptych with silver appliqués, set with precious stones, depicting the Virgin Mary with the Child and Vernicle. It was painted in Cracow around 1440-1450 and was funded by the cathedral curate Maciej of Grodziec. 